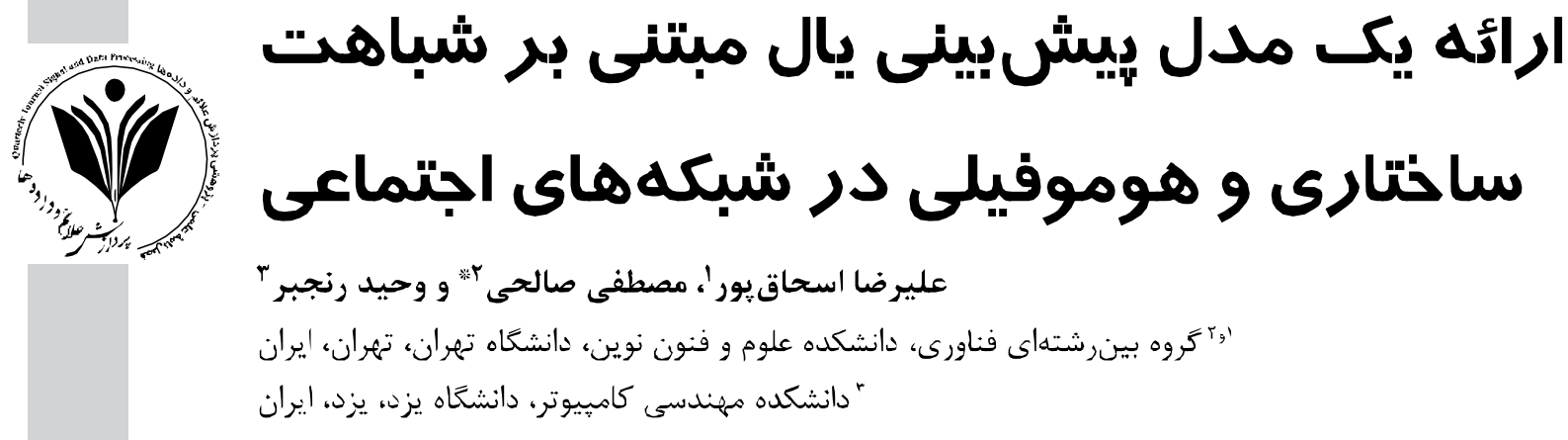

OU ? در سال هاى اخير شبكه هاى اجتماعى مجازى روز به روز در حال رشد و تغيير هستند. يال هاى جديد نشاندهندهُ تعاملات ميان ترهها هستند

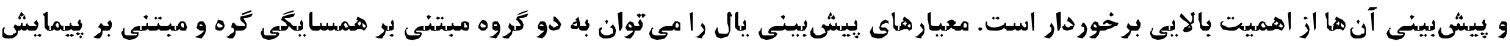

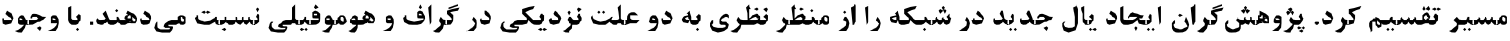

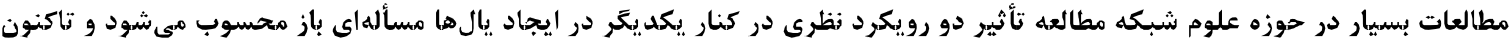

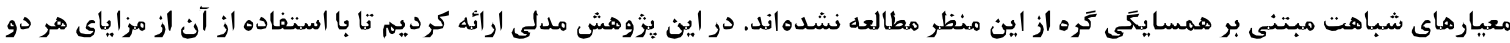

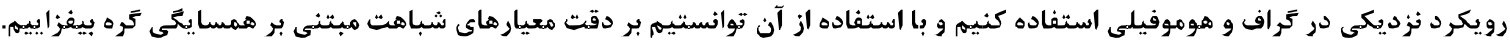

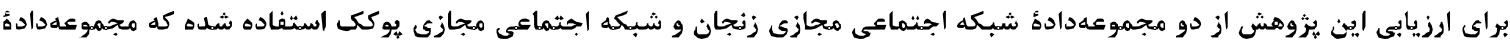

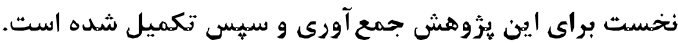

وازًٔان كليدى: بِيشبينى يال، شباهت هوموفيلمى، شباهت ساختارى، شبكههاى اجتماعى

\title{
Providing a Link Prediction Model based on Structural and Homophily Similarity in Social Networks
}

\author{
Alireza Eshaghpour ${ }^{1}$, Mostafa Salchi ${ }^{2 *}$ \& Vahid Ranjbar ${ }^{3}$ \\ 1,2 Faculty of New Sciences and Technologies, Tehran University, Tehran \\ ${ }^{3}$ Department of Computer Engineering, Yazd University, Yazd
}

\begin{abstract}
In recent years, with the growing number of online social networks, these networks have become one of the best markets for advertising and commerce, so studying these networks is very important. Most online social networks are growing and changing with new communications (new edges). Forecasting new edges in online social networks can give us a better understanding of the growth of these networks. Link prediction has many important applications. These include predicting future social networking interactions, the ability to manage and design useful organizational communications, and predicting and preventing relationships in terrorist gangs.

There have been many studies of link prediction in the field of engineering and humanities. Scientists attribute the existence of a new relationship between two individuals for two reasons: 1) Proximity to the graph (structure) 2) Similar properties of the two individuals (Homophile law). Based on the two approaches mentioned, many studies have been carried out and the researchers have presented different similarity metrics for each category. However, studying the impact of the two approaches working together to create new edges remains an open problem.
\end{abstract}

* Corresponding author

*ويسنده عهدهدار مكاتبات

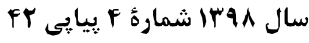

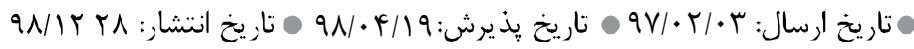


Similarity metrics can also be divided into two categories; Neighborhood-based and path-based. Neighborhood-based metrics have the advantage that they do not need to access the whole graph to compute, whereas the whole graph must be available at the same time to calculate path -based metrics.

So far, above the two theoretical approaches (proximity and homophile) have not been found together in the neighborhood-based metrics. In this paper, we first attempt to provide a solution to determine importance of the proximity to the graph and similar features in the connectivity of the graphs. Then obtained weights are assigned to both proximity and homophile. Then the best similarity metric in each approach are obtained. Finally, the selected metric of homophily similarity and structural similarity are combined with the obtained weights.

The results of this study were evaluated on two datasets; Zanjan University Graduate School of Social Sciences and Pokec online Social Network. The first data set was collected for this study and then the questionnaires and data collection methods were filled out. Since this dataset is one of the few Iranian datasets that has been compiled with its users' specifications, it can be of great value. In this paper, we have been able to increase the accuracy of Neighborhood-based similarity metric by using two proximity in graph and homophily approaches.

Keywords: Link prediction, Homophily similarity, Network similarity, Social networks

$$
\begin{aligned}
& \text { تيشبينى يال، كاربردهاى بسيار ههمى دارد. از جمله }
\end{aligned}
$$

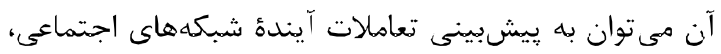

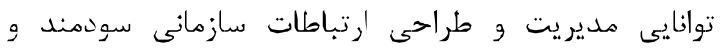

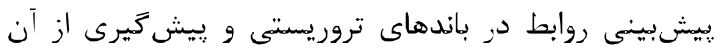

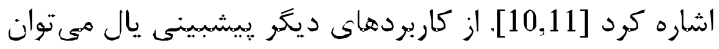

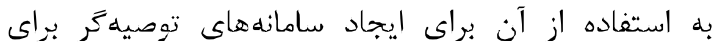

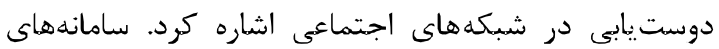

$$
\begin{aligned}
& \text { توصيه كر، سامانdهايى هستند كه بd كمك اطلاعات موجود و } \\
& \text { تحليل رفتار و خوصوصيات كاربران، بِيشنهادهاى خودكارى } \\
& \text { به آنها ارائه مى دهند }
\end{aligned}
$$

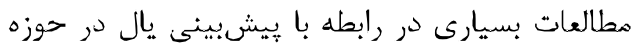

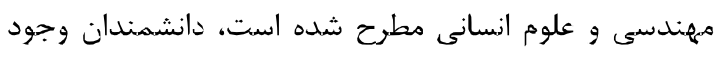

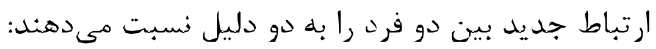

$$
\begin{aligned}
& \text { 1- نزديكى نر كراف (ساختار) }
\end{aligned}
$$

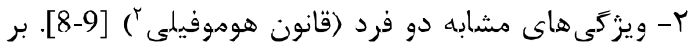

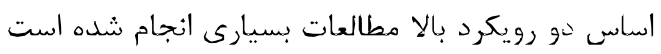

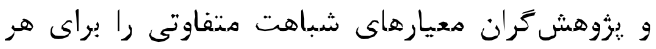

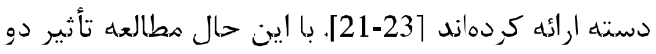

$$
\begin{aligned}
& \text { رويكرد بالا در كنار يكديگر در ايجاد يالهاي دهاي جديد } \\
& \text { همجنان مسألهاى باز هحسوب مى دئرد. }
\end{aligned}
$$

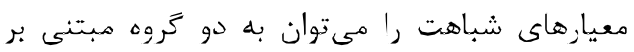

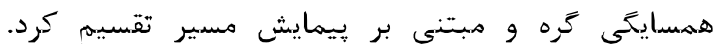

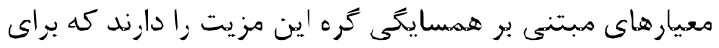

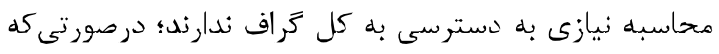

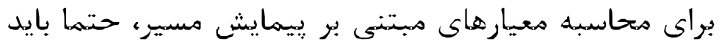

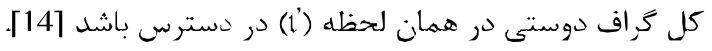

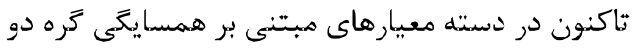

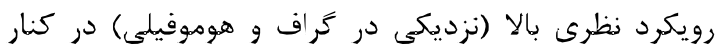

${ }^{1}$ Close in network

${ }^{2}$ I Iomophily

$$
\begin{aligned}
& \text { 4olقo -1 } \\
& \text { از دهه دوم قرن آك، شاهديهم كه مجموعهاى از افراد از طريق }
\end{aligned}
$$

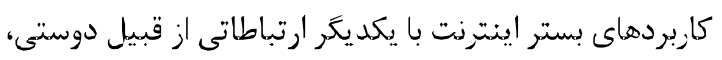

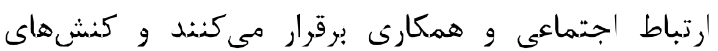

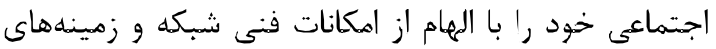

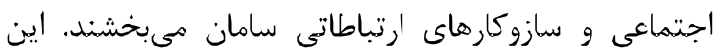

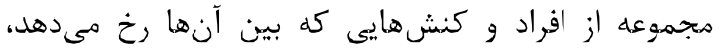

$$
\begin{aligned}
& \text { شبكههاى اجتماعى هجازى را تشكيل هى دهند. هرجيند آمار } \\
& \text { دقيقى براى تعداد كاربران شبكه هاى اجتماعى مجازى وجود }
\end{aligned}
$$

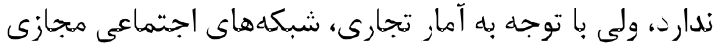

$$
\begin{aligned}
& \text { در سالهاى اخير توانستهاند تعداد كاربران بسيار بالايى را باديه }
\end{aligned}
$$

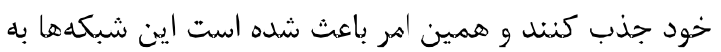

$$
\begin{aligned}
& \text { يكى از بهترين بازارها براى تبليغات و تجارت تبديل شوند لـ }
\end{aligned}
$$

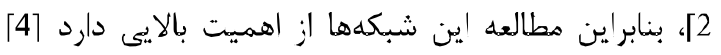

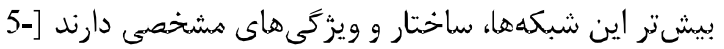

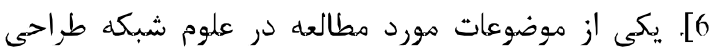

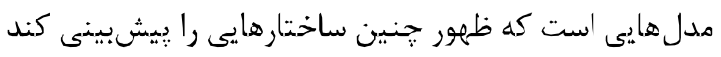

$$
\begin{aligned}
& {[3,7,8]} \\
& \text { بسيارى از شبكdهاى اجتماعى هجازى، بهشدت يويا } \\
& \text { بوده و با اضافهشدن يالهاى جديد در حال زشد و تغييزند. }
\end{aligned}
$$

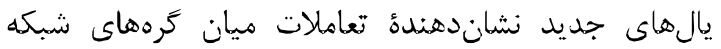

$$
\begin{aligned}
& \text { هستند؛ بنابر اين مطالعه شبكههاى اجتماعى در سطح يال ها و و } \\
& \text { كرهها مى تواند درك بهترى از هكانيزم رشد شبكهها در اختيار } \\
& \text { ها قرار دهد كه به واسطه آن مى توان به طراحى هدلى براى }
\end{aligned}
$$

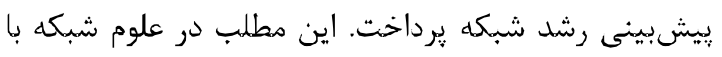

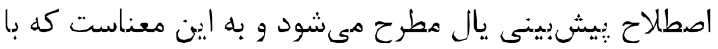

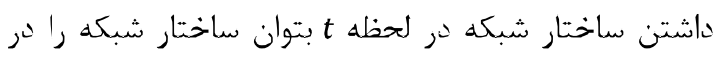

$$
\begin{aligned}
& \text { آيندة نزديك در زمان }
\end{aligned}
$$

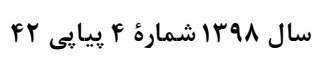


نتايج اين يزوهش بر روى دو مجموعه داده شبكه

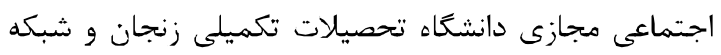

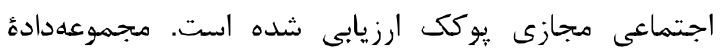

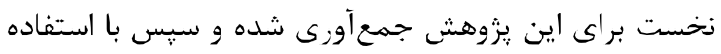

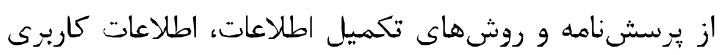

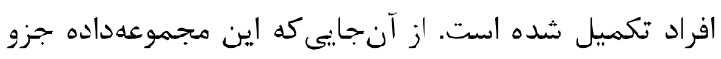

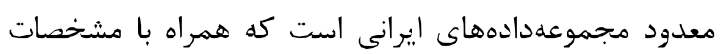
كاربران آن جمعآورى شده است، مى تواند ارزش بالايى داشته

باشد.
يكديخر ديده نشده است. در اين يُوهش با ارائه يك مدل كه ساختار آن در شكل (1) ملاحظه مىشود، توانستيهم با استفاده

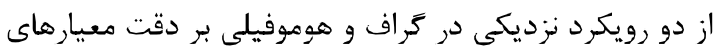

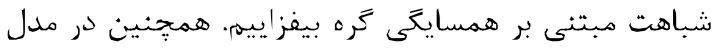

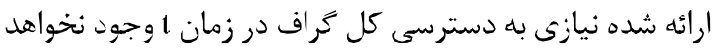

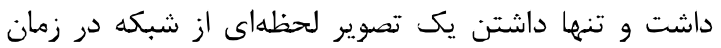

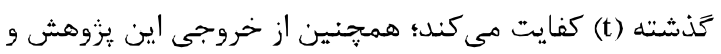
وزن هايى كه براى هوموفيلى شبكه و ساختار شبكه حاصل

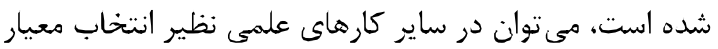

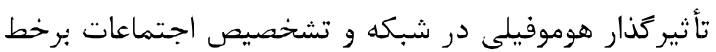

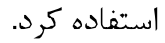

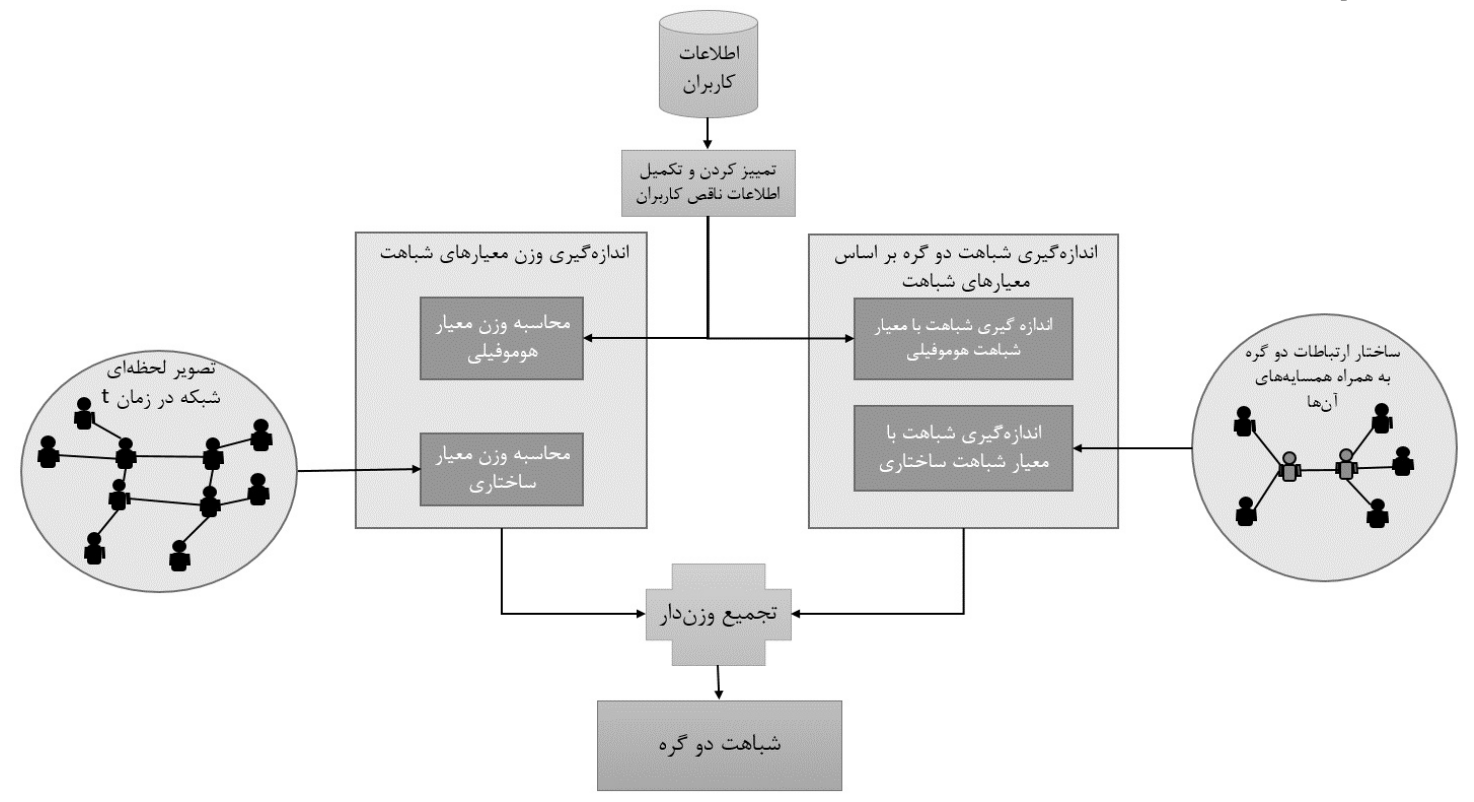

(شكل-1): ساختار روش بيشنهادى

(Figure-1): The structure of the proposed approach

داده است كه هر جقدبر دو فرد در كراف دوستى به يكديكر

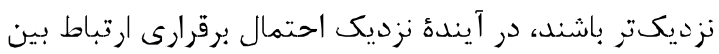

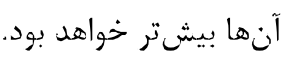

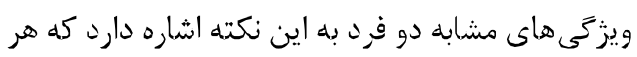
جقدر دو فرد داراى ويزگى هاى مشابه بيشترى باشند، احتمال

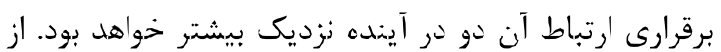

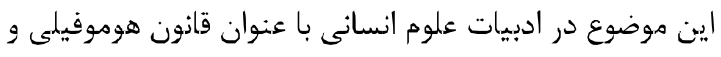

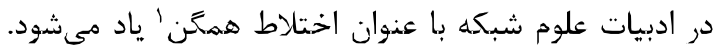

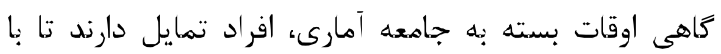

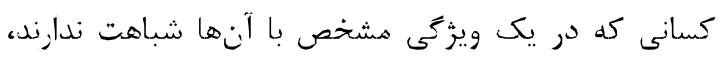

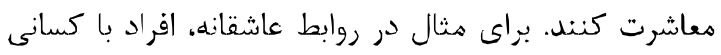

${ }^{1}$ Assortative mixing

\section{r- بيشينة موضوع}

در حوزة مهندسى و علوم انسانى درخصوص بِيشبينى يال،

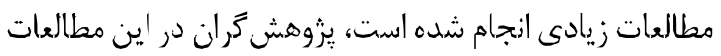

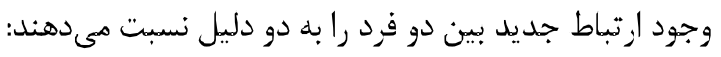

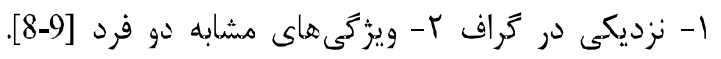

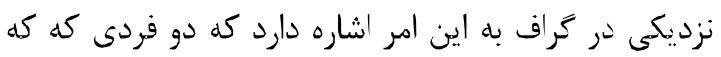

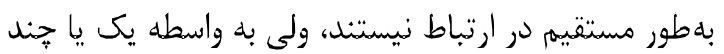

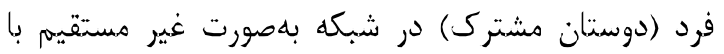

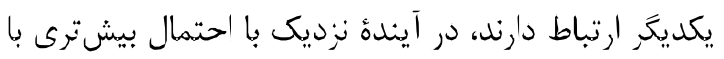

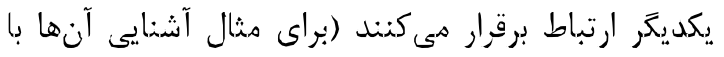
يكديكر در مهمانى از طريق دوست مشترك). مطالعات نشان انئ 
از رويكردى ديكر مى توان معيارهاى شباهت را به دو

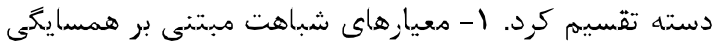

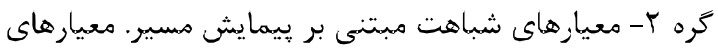

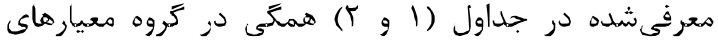

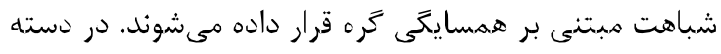

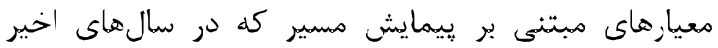

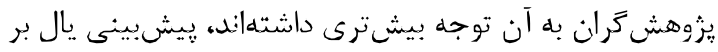

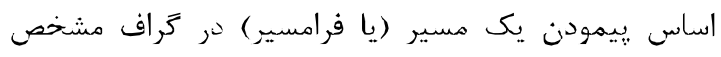

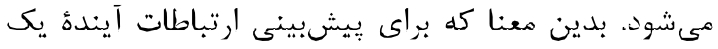

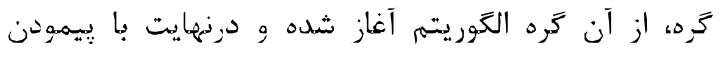

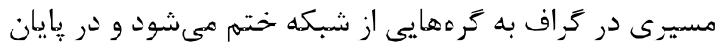

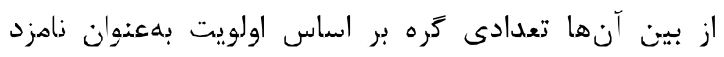

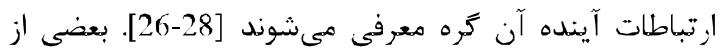

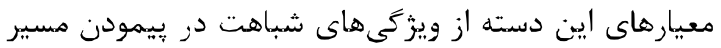

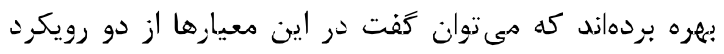

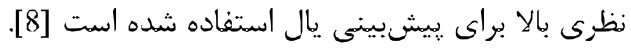

\begin{tabular}{|c|c|c|}
\hline مر جع & سال & معيار شباهت \\
\hline$\lceil 15\rceil$ & 1986 & همريوشانى \\
\hline$|16|$ & 1966 & تودال \\
\hline$|17|$ & 2002 & اسكين \\
\hline$\lceil 11]$ & 2008 & IOF \\
\hline$[12]$ & 2013 & $\mathrm{OF}$ \\
\hline
\end{tabular}

با توجه به دقت بالاتر معيارهاى دسته مبتنى بر

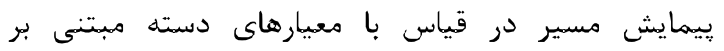

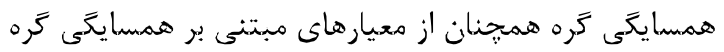

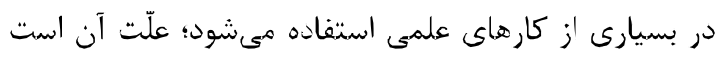
كه براى محاسبه معيارهاى شبالهت مبتنى بر همسايكى كره،

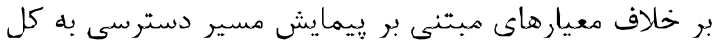

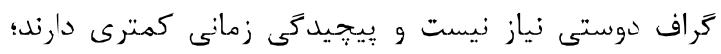

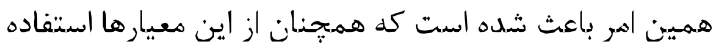

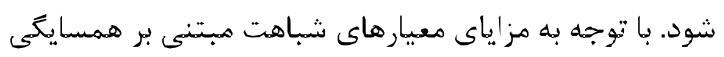

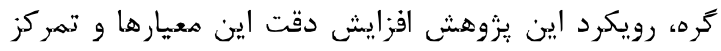
اصلى بر روى اين دسته از معيارها است.

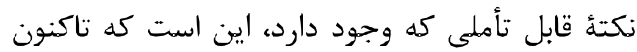

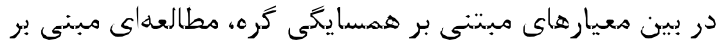

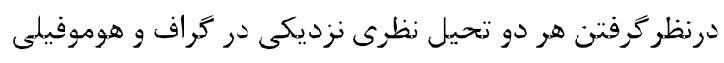
در كنار يكديگر ديده نشده است. با وجود اين امر در اين فردئ
كه جنسيت متفاوتى با آنها دارند معاشرت مى كنند؛ يا در

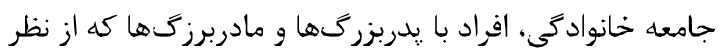

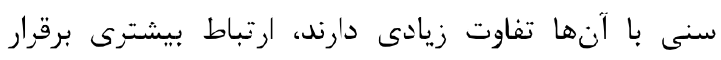

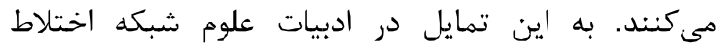

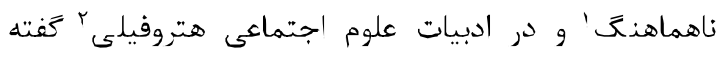

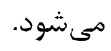
بديهى است، نزديكى در كراف و هوموفيلى، بهالزام از

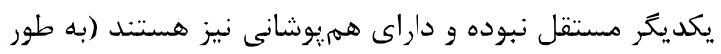

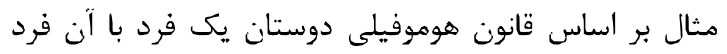

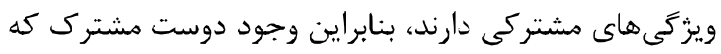
مبين نزديكى در كراف است، با قانون هوموفيلى نيز، قابل دابل توجيه است).

در حوزه مهندسى، بيشتر بر بر روى نزديكى در تراف

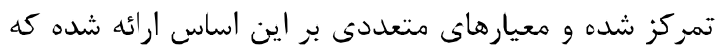

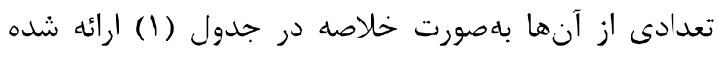

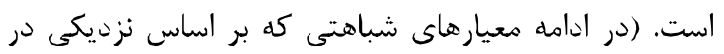

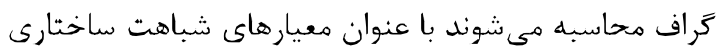

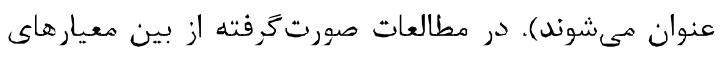

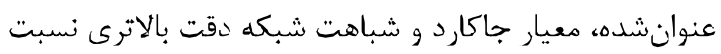
به ساير هعيارها كسب كردهاند |25|. (جدول - (): معيار هاى شباهت ساختارى (Table-1): Network similarity

\begin{tabular}{|c|c|c|}
\hline مر جع & سال & ميعيار شباهت \\
\hline$[18]$ & 1901 & ضريب جاكارد \\
\hline$[19]$ & 1991 & همبستحَى نقطه به زقطه اطلاعات مشترى \\
\hline$[20]$ & 2003 & آداميك و آدار \\
\hline$[24]$ & 2004 & كسينوس \\
\hline$[12]$ & 2013 & شباهت شبكه \\
\hline
\end{tabular}

در حوزء علوم انسانى يزوهش كران به مباحث نظرى

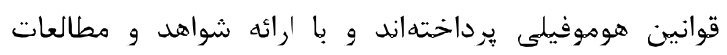

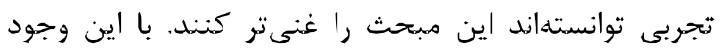

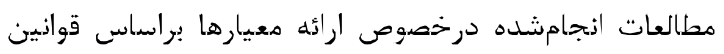

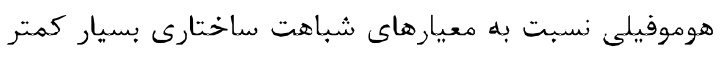

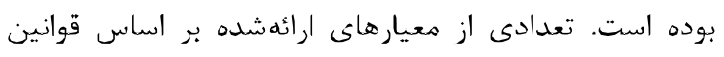

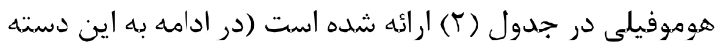

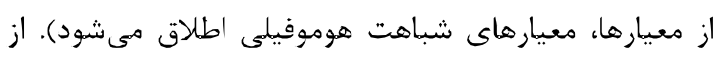

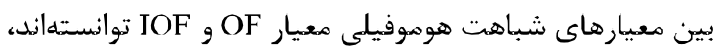

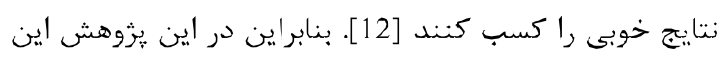

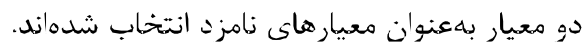

${ }^{1}$ Disassortative mixing

${ }^{2}$ Hetrophily 


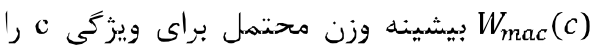

نشان مى دهد و W(c) بيانَ

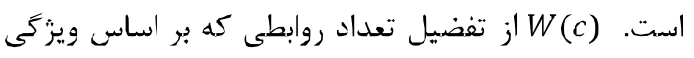

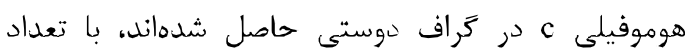
روابطى كه بر اساس اين ويزگى هوموفيلى در كراف تصادفى درى درافي

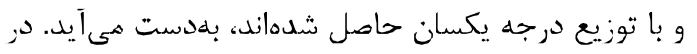
اين رابطه

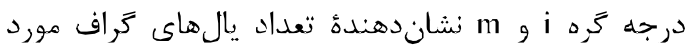
مطالعه هستند. همجنين

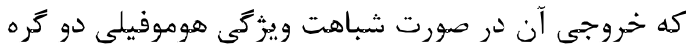

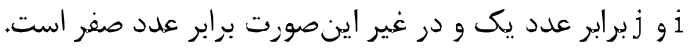

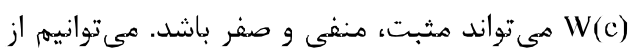
بازههاى عددى وزن حاصل، نتايج زير را بخيريه: :W(c) > 0

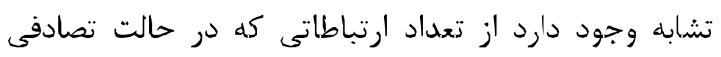

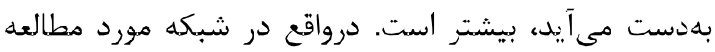

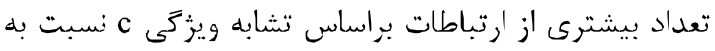
مقدار مورد انتظار داريم؛ بنابراين براى ويزَّى c دو نتيجه

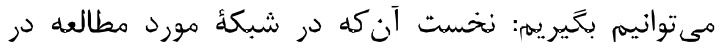

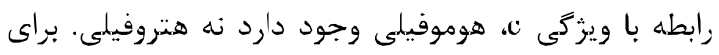
هثال در شبكه دانشجويان، افراد با تحصيلات يكسان با يكديكر

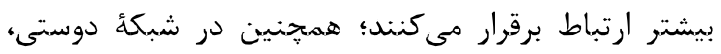

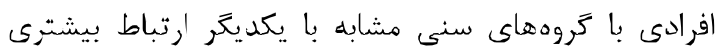

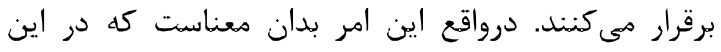

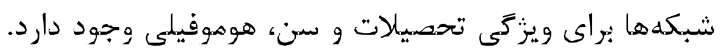

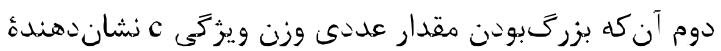

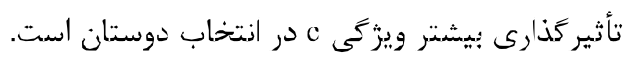
اله تشابه وجود دارد، از تعداد ارتباطاتى كه در حالت الت تصادفى آنى

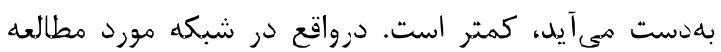

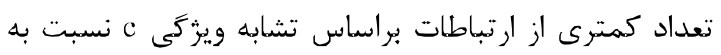

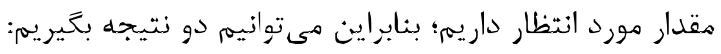

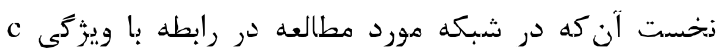

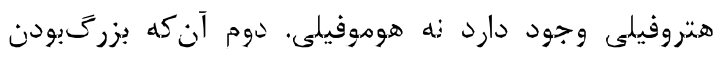

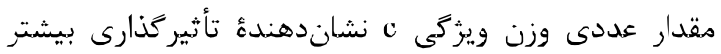

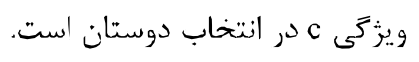

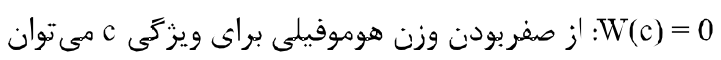

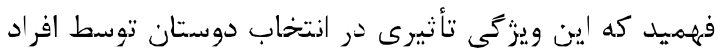

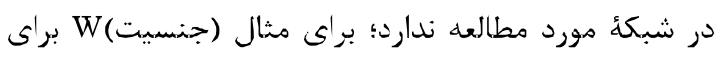

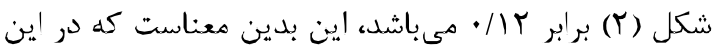

يزوهش ما بهدنبال آن هستيم تا با ارائه يك روش، علاوهبر

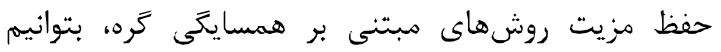

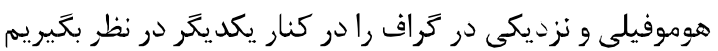
تا بتوانيم بر دقت اين معيارها بيافزاييه.

\section{r- روش اندازهَيرى}

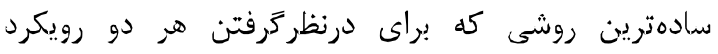

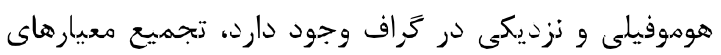

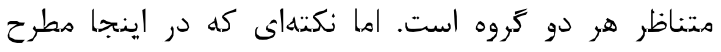

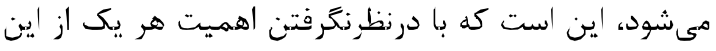

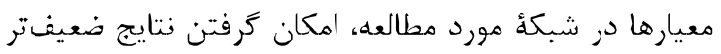
وجود خواهد داشت.

در اين يزوهش فرض شد شده است كه ساختار شبكه در

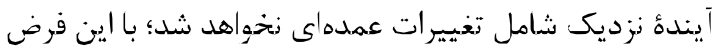

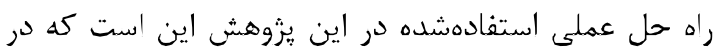

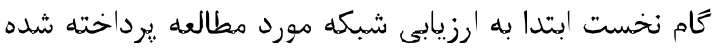

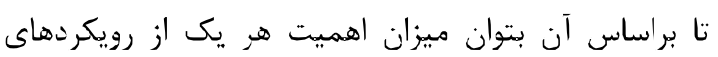

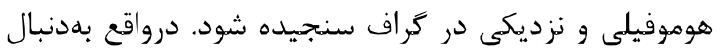

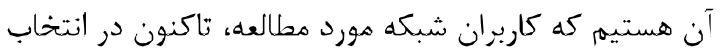

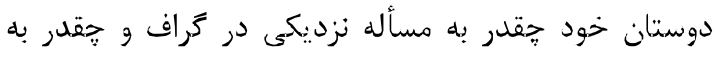

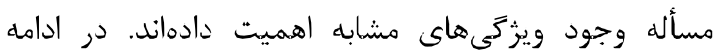

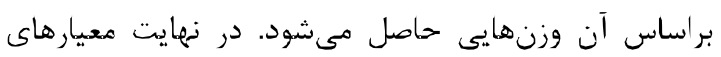

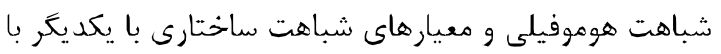

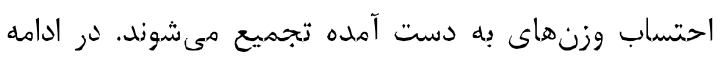
نحوه محاسبه وزنها براى هر يك از دو رويكرد هوموفيلى و

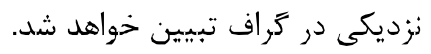

\section{ا-r- ازدازهَيرى وزن ويثَّى هاى هوموفيلى}

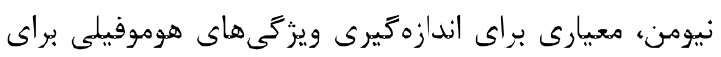

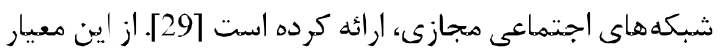
مى توان براى هشخص كردن وزن ويزگى هاى هوهوفيلى براى

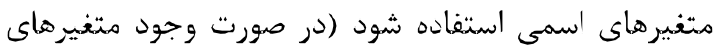

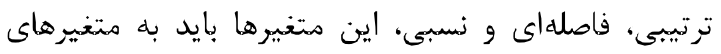
اسمى تبديل شوند)؛ بنابراين در اين كار براى تعيين وزين إنداين

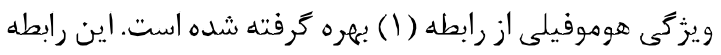

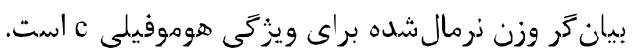

$\frac{W(c)}{W_{\max }(c)}=\frac{\sum_{i j}\left(A_{i j}-\frac{k_{i} k_{j}}{2 m}\right) \delta\left(c_{i}, c_{j}\right)}{2 m-\sum_{i j} \frac{k_{i} k_{j}}{2 m} \delta\left(c_{i}, c_{j}\right)}$ 
كر اف كامل بّ را تعيين هى كند و از رابطه (r) براى كره هشخص حاصل مىشون: i

$\mathrm{C}_{\mathrm{i}}=\frac{2 \mathrm{e}_{\mathrm{i}}}{\mathrm{k}_{\mathrm{i}}\left(\mathrm{k}_{\mathrm{i}}-1\right)}$

كه در آن أن برابر تعداد اتصالاتى است كه بين

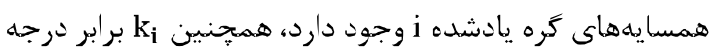

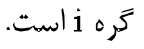

فرض كنيد

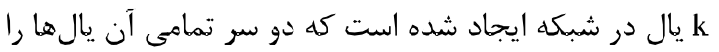

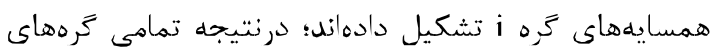

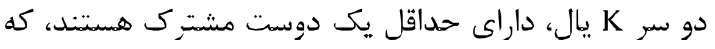

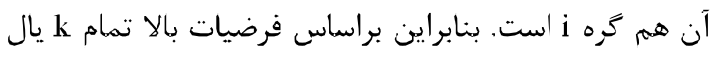

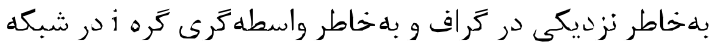

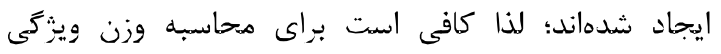
ساختارى براى هر گره اين مقدار را تقسيهم بر مقدار بيشينه

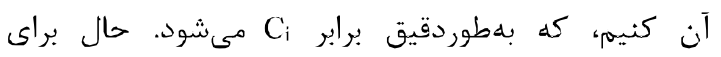

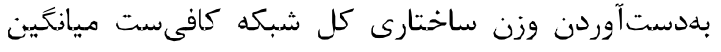

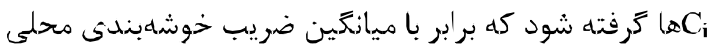

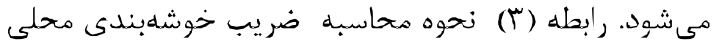

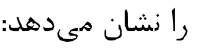

$\overline{\mathrm{C}}=\frac{1}{n} \sum_{i}^{n} \frac{2 e_{i}}{k_{i}\left(k_{i}-1\right)}$

ضريب خوشهبندى سراسرى": هعيارى است كه ميزان

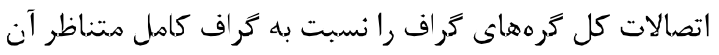

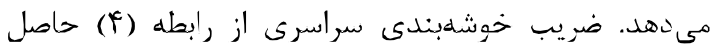

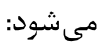

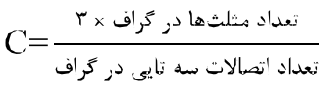

موتيف سهتايى بستهه: در علوم شبكه مطالعاتى در

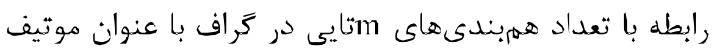

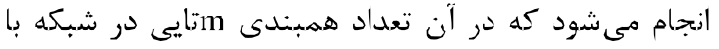

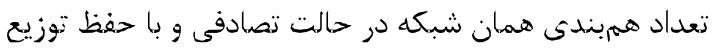

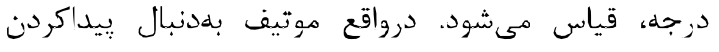

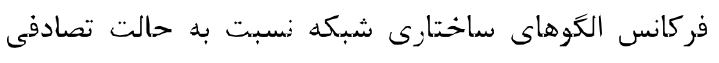

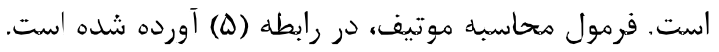
موتيف را بهصورت Motif

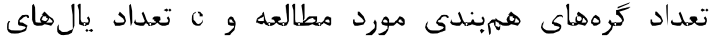

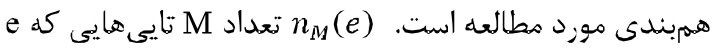

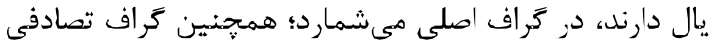

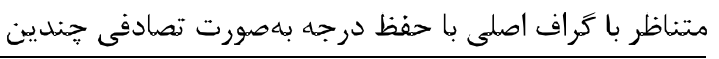

\footnotetext{
${ }^{3}$ Clique (Complete graph)

${ }^{4}$ Global Clustering Cocfficient

5 Motif (3)
}

شبكه مشابهت جنسيت باعث افزايش احتمال دوستى بين

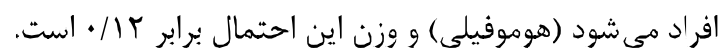

\section{r-r - اندازهيرى وزن ويثَى ساختارى}

همانطور كه در بخش يِشينه موضوع بيان شد، الكوى

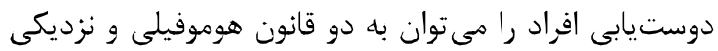

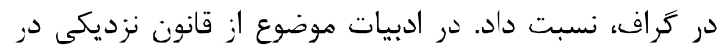

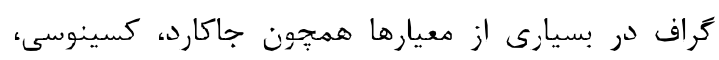

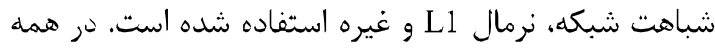
آنها يك فرض سادهسازى به طور مستقيم استفاده شده است،

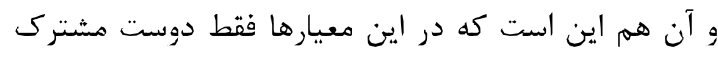

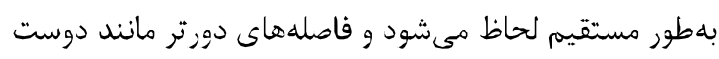

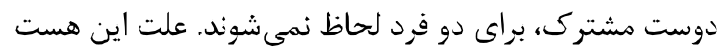

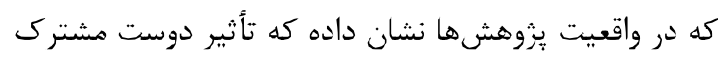

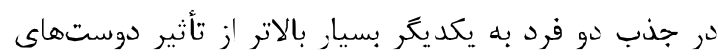
مشترك، با واسطههاى بيشتر است.

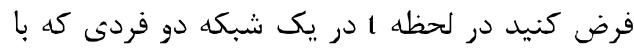

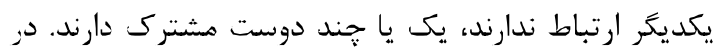

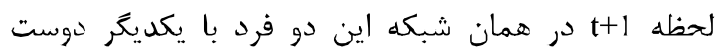

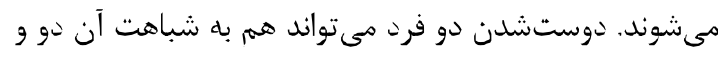

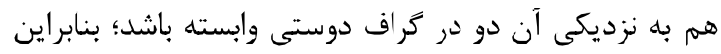

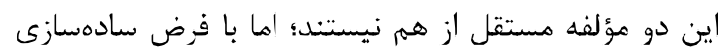

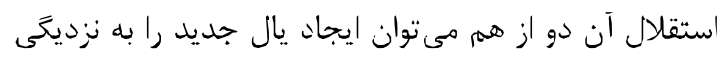

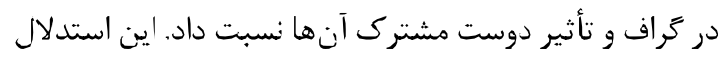

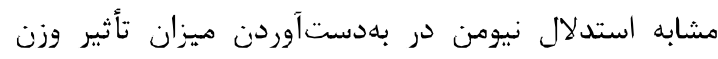

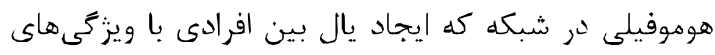

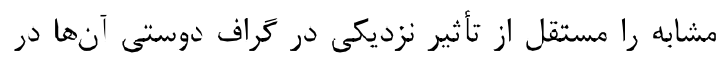
نظر كرفتهاند، است [29].

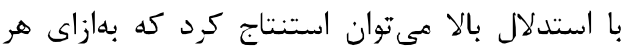

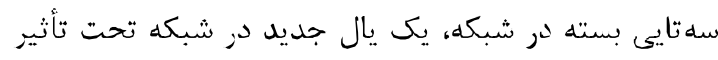

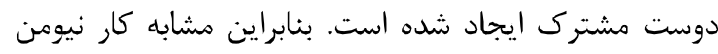

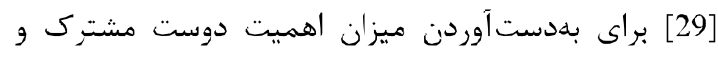

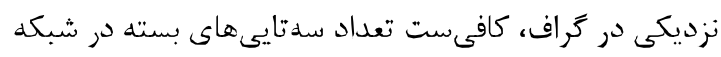

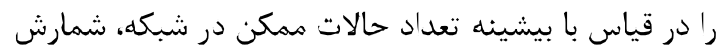

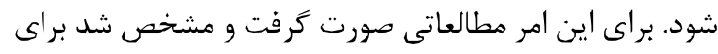

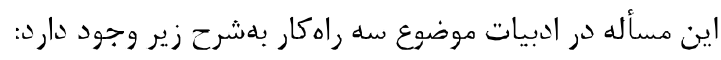

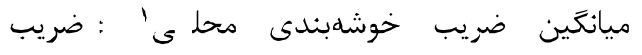

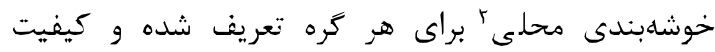

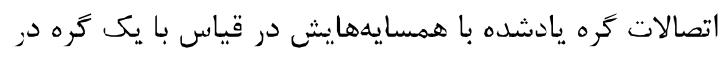

${ }^{1}$ Average Local Cluster Coefficient

${ }^{2}$ Local Clustring Cofficient 
شبكة اجتماعى مجازى دانشعًاه ت تحصيلات تكميلى زنجان': اين شبكه اجتماعى هجازى، كار خود را از از

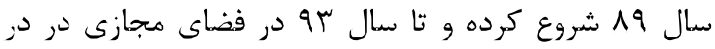
دسترس بوده است. حدود ششصد دانشجو درد در دانشياه تحصيلات تكميلى زنجان مشغول به تحصيل بودماند كه از اين

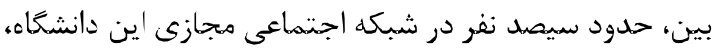

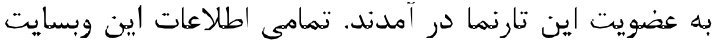

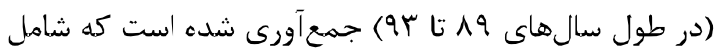

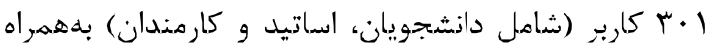

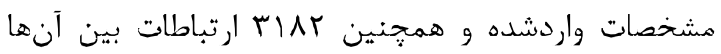

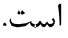

\section{تكميل اطلاعات مشخصات كاربران}

بسيارى از هجموعهدالدهاى جمعآورىشده از شبكهذهاى اجتماعى مجازى بهدلايل مختلف از قبيل ير نير نكردن تمام

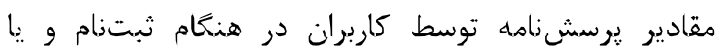
فعال سازى سطح حريم خصوصى توسط كاربران (كه در اين

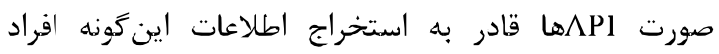
نيستند) داراى نقصان اطلاعات هستند. همين موضوع باعث

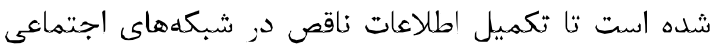

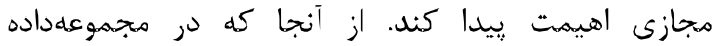

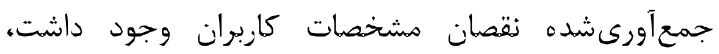

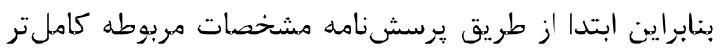

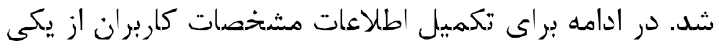

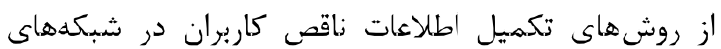

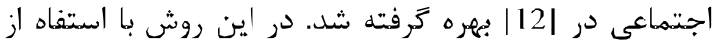

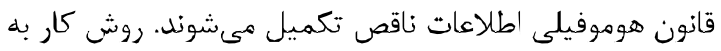
اين صورت هست كه اطلاعات ناقص ويزّكى ألم (براى مثال

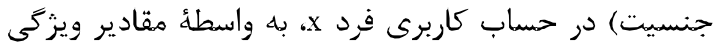

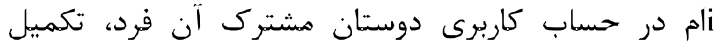

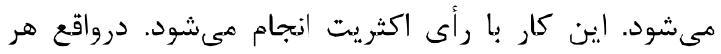

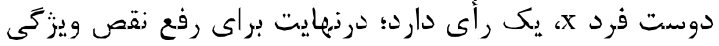

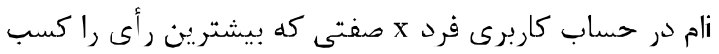

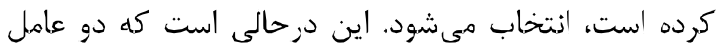

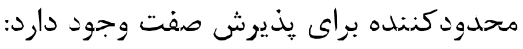

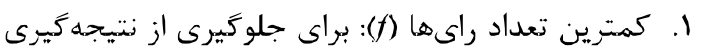

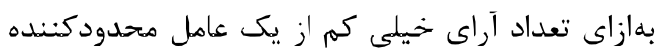

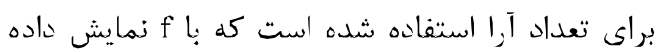

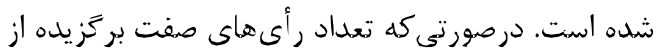

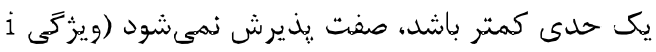

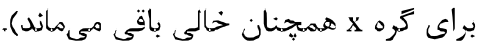

${ }^{1}$ http://coinlab.ut.ac.ir/resources

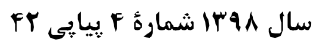

مرتبه ساخته مىشود و ميانكين و انحراف معيار همبندىهاى

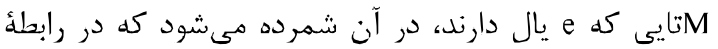

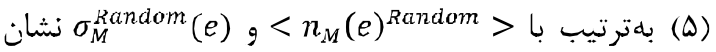

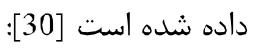

$\operatorname{Motif}_{M}(e)=\frac{n_{M}(e)-<n_{M}(e)^{\text {Random }}>}{\sigma_{M}^{\text {Random }}(e)}$

از آنجا كه ميانخين ضريب خوشهبندى محلى بهازاى

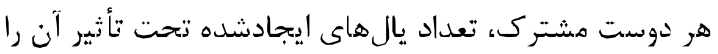

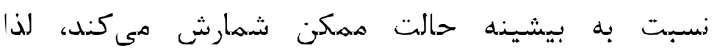
نزديكترين روش از سه روش بالا، اين روش است؛ درنهايت

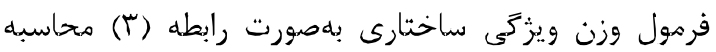
مى شود: بنابراين با توجه به شكل (1) مهاسبه وزن معيار

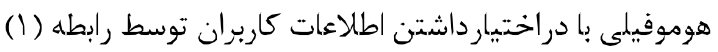
و محاسبه وزن معيار ساختارى با دراختيارداشتن تصوير

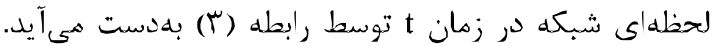

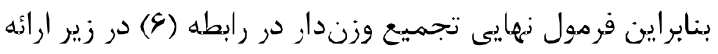
شده است. - ماتس

$P(X, Y)=($

$$
\begin{cases}\frac{\frac{W(c)}{W_{\max (c)}+\left(W_{\text {Structural }} \times N S(u, x)\right)}}{\frac{W(c)}{W_{\max }(c)}+W_{\text {Structural }}} & \text { if } X_{k}=Y_{k} \\ \frac{\left(\frac{W(c)}{W_{\max }(c)} \times S_{k}\left(X_{k}, Y_{k}\right)\right)+\left(W_{\text {structural }} \times N S(u, x)\right)}{\frac{W(c]}{W_{\max (c)}}+W_{\text {Structural }}} & \text {, } \text { Otherwise }\end{cases}
$$

در اين رابطه WStructural برابر رابطه (\&)، NS(u,x) برابر OF معيار شباهت شبكه و

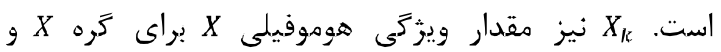
همجنين P(X,Y) برابر احتمال ايجاد يال بين دو كره X

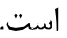

\section{F}

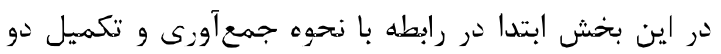

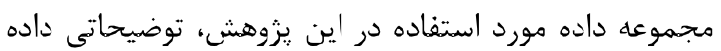
شده است، در ادامه به تبيين سناريوى ارزيابى و درنهايت به به داديه

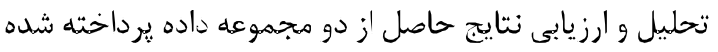

1-F- مجموعهداده

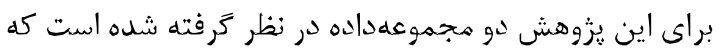
در ادامه هر يك تبيين خواهند شد. 
شبكه اجتماعى دانشخاه تحصيلات تكميلى زنجان در جدول

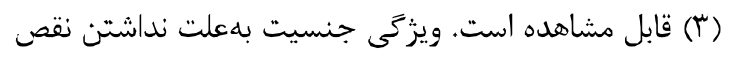

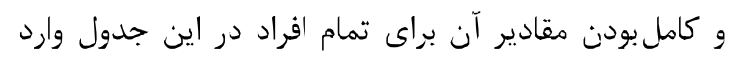

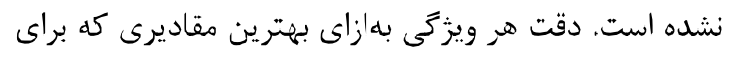

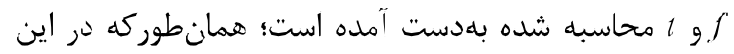

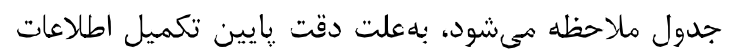

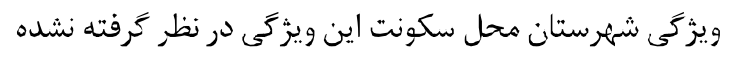

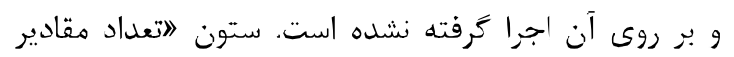

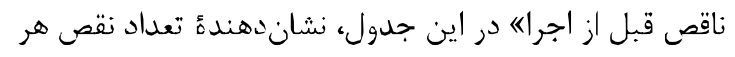

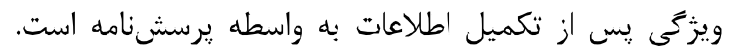

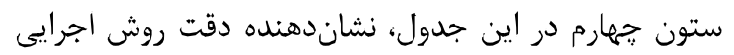

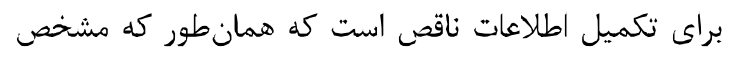

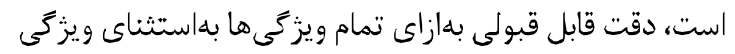

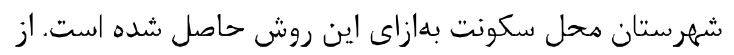

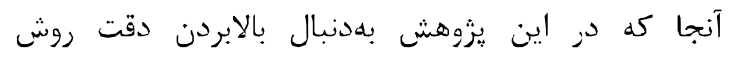

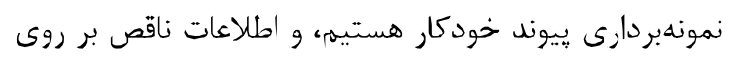

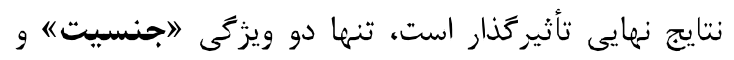

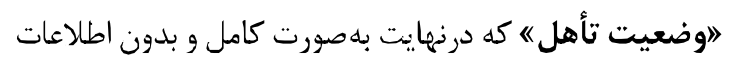

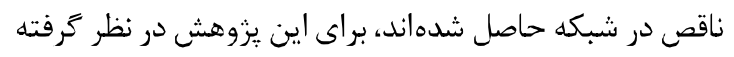

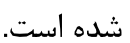

r. بيشينه قاطع در رأى بيرى (l): براى جلوكيرى از

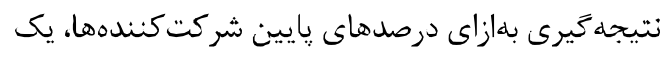

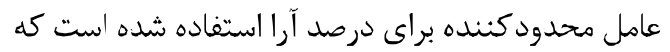

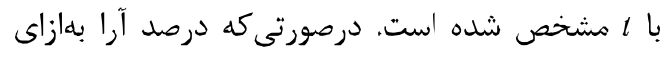

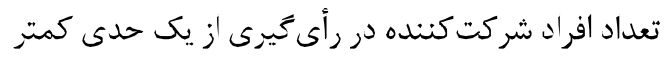

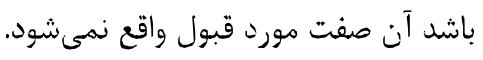

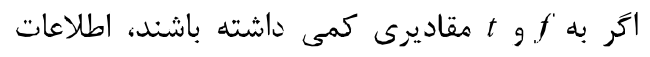

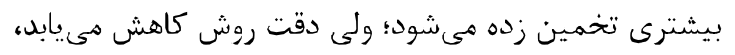

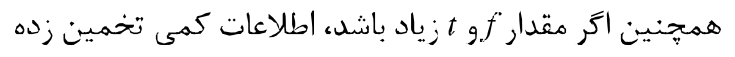

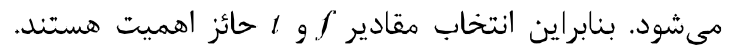

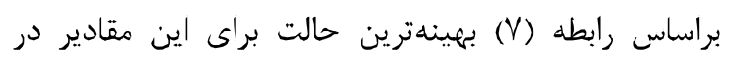
مجموعه دادة آموزشى بلهدست مى آيد.

$L(f, t)=\operatorname{Precision}(f, t) \times \log (C(f, t))$

كه نر آن Precision $(f, t)$

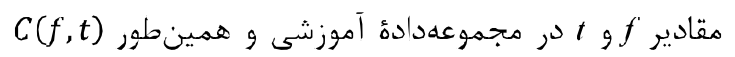
تعداد تخمينهاى درست در مجموعوعه داده آموزشى است. باديا

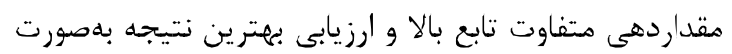

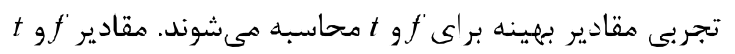

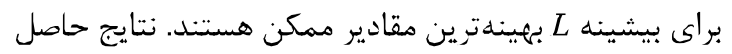

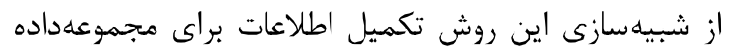

(جدول -r) : نتايج تكميل اطلاعات ناقص مجموعه داده شبكه اجتماعى مجازى دافشكاه تحصيلات تكميلى زنجان

(Table-3): Result of complete missing data on IASBS Social

\begin{tabular}{|c|c|c|c|c|c|c|}
\hline & $\mathrm{f}$ & $\mathrm{t}$ & تعداد مقادير يیشبينى شده & دقت & تعداد مقادير ناقص قبل از & $\begin{array}{c}\text { درصد مقادير ناقص باقى مانده } \\
\text { بعد از اجرا }\end{array}$ \\
\hline وضعيت تاهل & 2 & 0.1 & 166 & 0.95 & 167 & 0 \\
\hline مقطع تحصيلى & 1 & 0.5 & 81 & 0.79 & 131 & 16.5 \\
\hline سال ورود به دانشكاه & 3 & 0.1 & 94 & 0.64 & 164 & 23 \\
\hline رشته تحصيلى & 1 & 0.5 & 89 & 0.89 & 156 & 22 \\
\hline شهرستان محل سكونت & 1 & 0.3 & 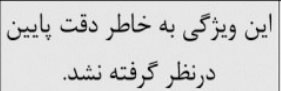 & 0.45 & 125 & - \\
\hline
\end{tabular}

بلهعلت حجيه:ودن اين مجموعلداده يك زمونهبردارى

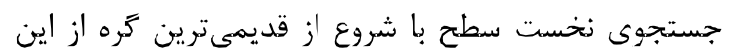

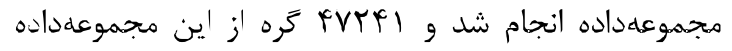

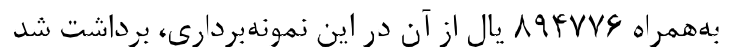

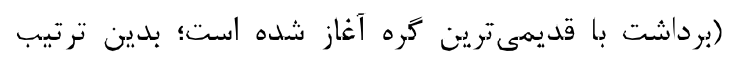
هى توان فرض كرد كه شبكأ حاصل از نمونهبردارى، شبكه اجتماءىى مجازى يوكى در سال هاى اوليه است).

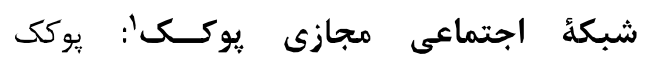
محبوبترين شبكه اجتماعى مجازى در كشور اسلواكى است كه حتى يس از آمدن فيسيوك، محبوبيت اين تارنما نزول

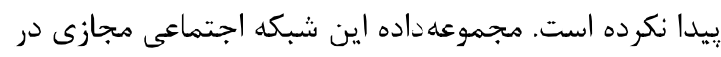
طول ده سال جمع آورى شده است كه شامل يكميليونيون و ششصد هزار كاربر هىشود [31]. اين هجموعهداده بر روى

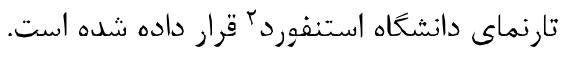

${ }^{1}$ Pokec

" إين مجموعه داده در يُيوند: https://snap.stanford.edu/data/soc-pokec.html در نسترس است. 
بيشتر از احتمال بهدستآهده براى يال ايجادنشده

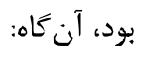

$n^{\prime}=n^{\prime}+1$

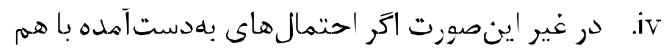

$n^{\prime \prime}=n^{\prime \prime}+1$

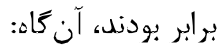

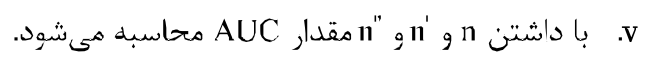

$A U C=\frac{n^{\prime}+0.5 n^{\prime \prime}}{n}$

e هقدار مجمرع AUC براى اجراهاى متفاوت محاسبه

$A U C_{\text {Total }}=A U C_{\text {Total }}+A U C$

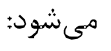

r. از ده اجراى كرفتهشده ميانكين كرفته و مقدار نهايى

$\Lambda U C_{\text {Finall }}=\frac{A U C_{\text {Total }}}{10}$

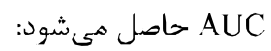

براى هجموعdداده شبكة اجتماعى هجازى دانشعاه

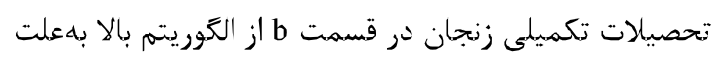

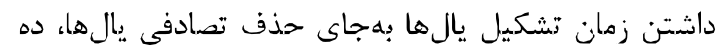

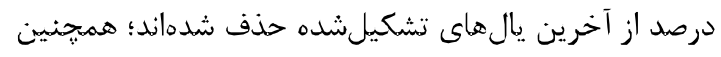

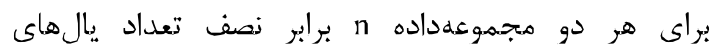
حذفشده در نظر كرفته شده است (درواقع n برابر است با بر بنج

$$
\text { درصد از كل يالهاى گراف اصلى). }
$$

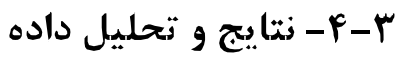

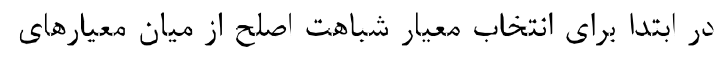

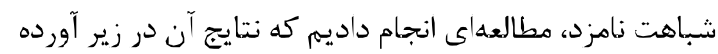

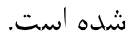

\section{1-F-F- انتخاب معيار اصلح از ميان معيارهاى نامزد شباهت}

نتايج بر روى مجموعهداده شبكأ اجتماعى مجازى دانشخاه

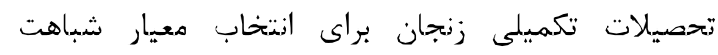

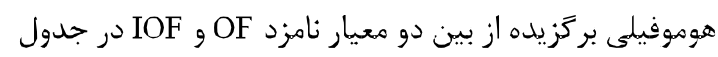

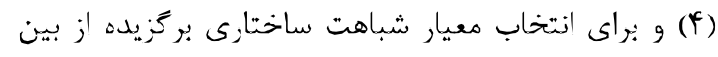

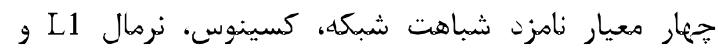

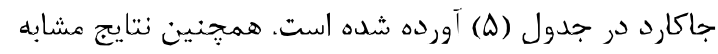

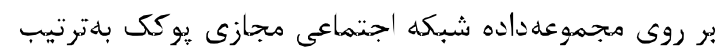

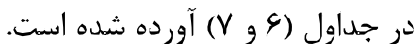

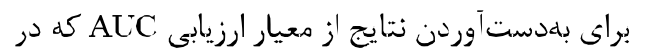

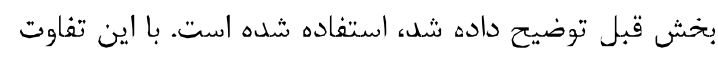

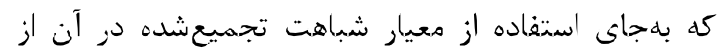

اين مجموعهداده داراى ويزگتىهاى زيادى است ولى الى

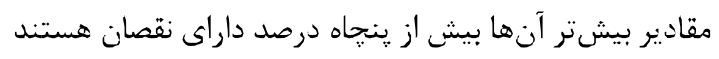

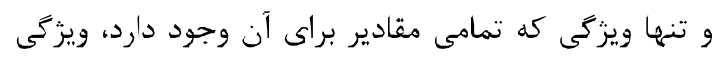

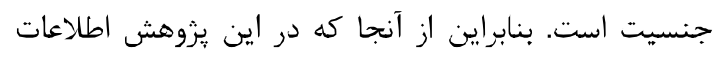

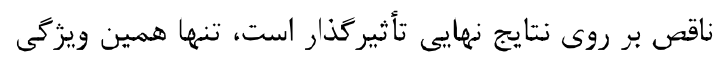
از اين مجموعهداده در نظر كرفته شده است.

$$
\text { r }
$$

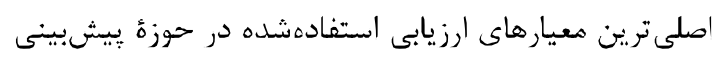

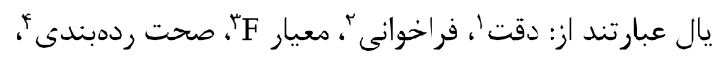

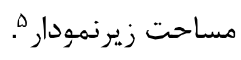

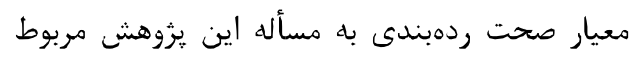

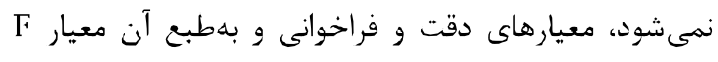

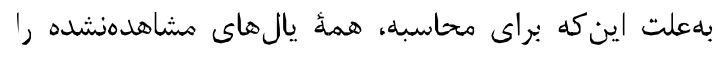

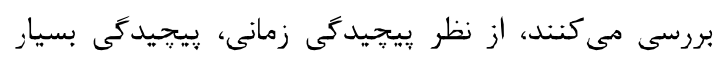

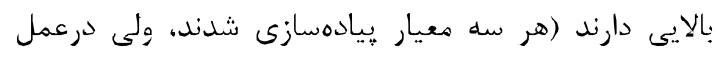

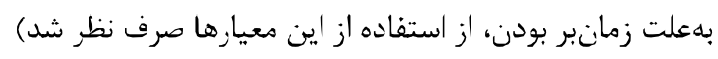

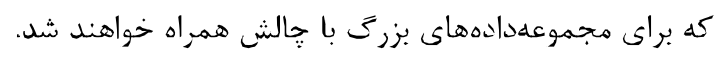

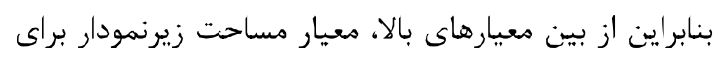

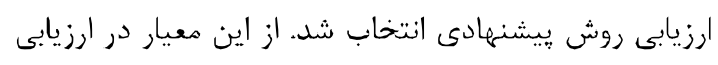

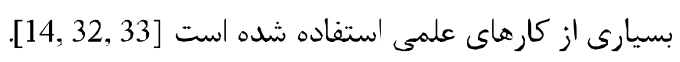
سناريوى ارزيابى به اين شرح است: 1. الكوريته زير به تعداد ده مرتبه انجام مى شيود.

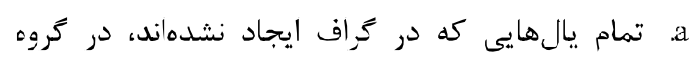

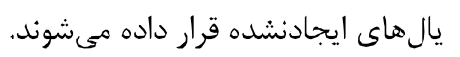

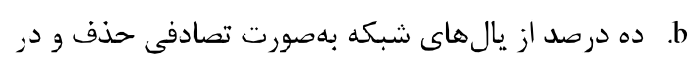
كروه يال هاى مشاهدهنشده قرار داده مي شيوند.

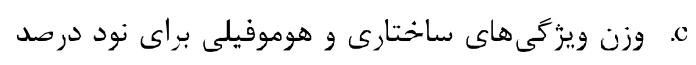

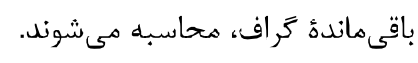

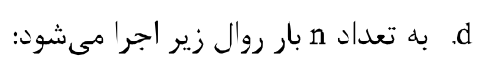

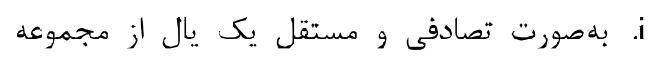

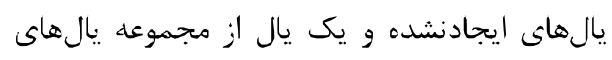

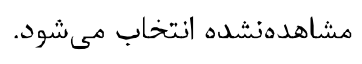

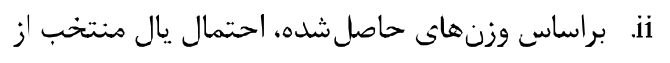

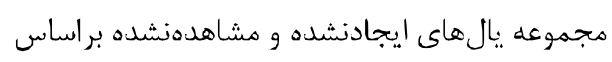

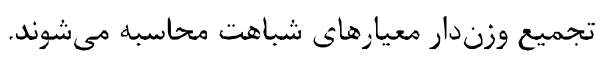
iii

\footnotetext{
${ }^{1}$ Precision

${ }^{2}$ Recall

${ }^{3}$ FMeasure

${ }^{4}$ Classification Accuracy

${ }^{5}$ Area Under Curve (AUC)
} 
(كفتنى است كه اعداد نوشتهشده همكى به دو رقهم اعشار كرد

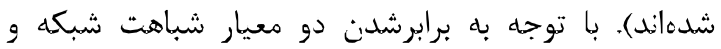

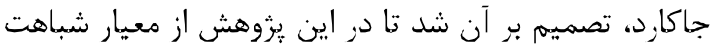
شبكه براى تعيين شباهت ساختارى، بجره كرفته شود.

(جدول-V-) : ارزيابى معيار اصلح از بين معيار هاى نامزد شباهت

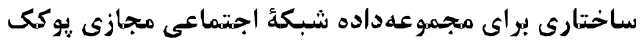

(Table-7): The evaluation of best similarity metrics between homophily similarity metries on Pokec Social

\begin{tabular}{|c|c|}
\hline معيار شباهت ساختلارى & 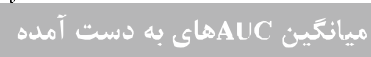 \\
\hline شباهت شبكه & 0.79 \\
\hline جاكارد & 0.79 \\
\hline شباهت كوسينوسى & 0.78 \\
\hline 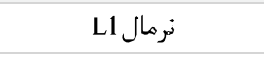 & 0.78 \\
\hline
\end{tabular}

r-r-r-r - ارزيابى و تحليل نتايج

در اين بخش توسط معيار ارزيابى مطرح شده، به ارزيابى و ودئي

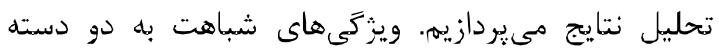

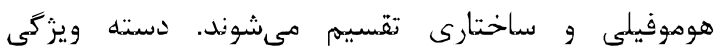

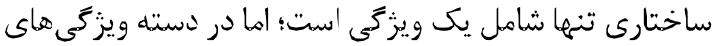

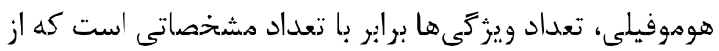

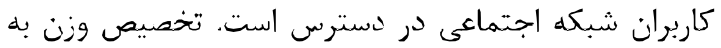

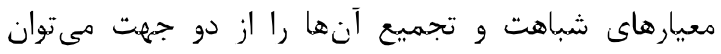

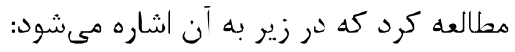

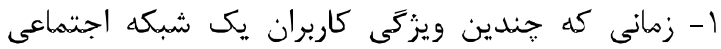

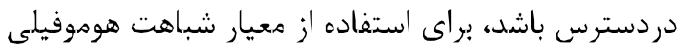

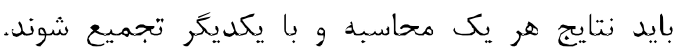

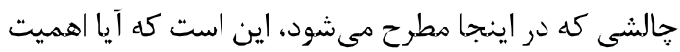

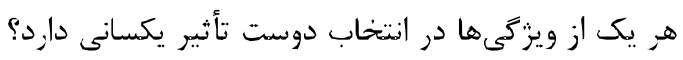

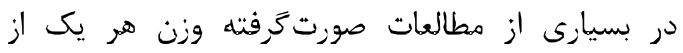

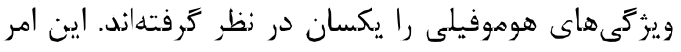

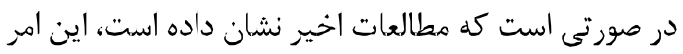

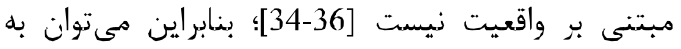

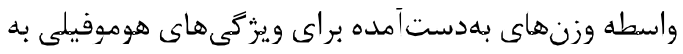

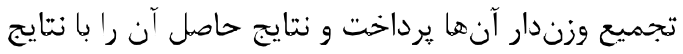

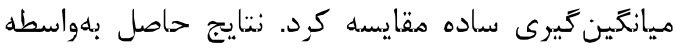
معيار ارزيابى مطرحشده بر روى مجموعهداداده شبكئ

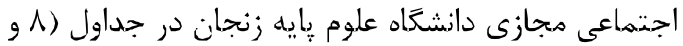

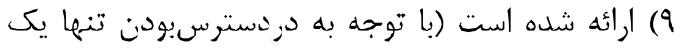

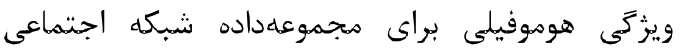
مجازى يوكىى، از اين مجموعهداده در اين بخش استفاده

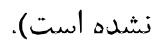

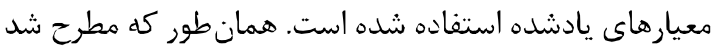

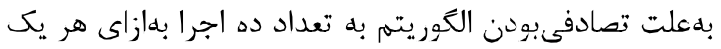

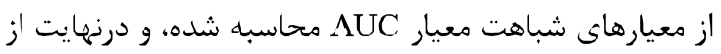

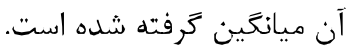

(جدول - P): ارزيابى معيار اصلح از بين معيار هاى نامزد شباهت

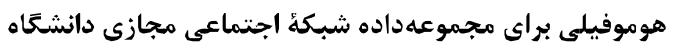
تحصيلات تكميلى علوم يايه زنجان.

(Table-4); The results of the evaluation of best similarity metrics between homophily similarity metrics on I ASBS Social

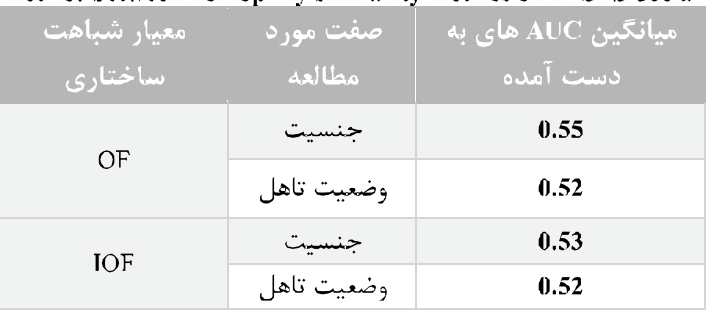

با توجه به نتايج حاصل از ارزيابى كه در جداول (f)

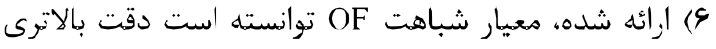

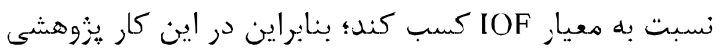
از بين معيارهاى شباهت هوموفيلى، اين معيار انتخاب شده

\section{(جدول - (ه): ارزيابى معيار اصلح از بين معيارهاى فامزد شباهت

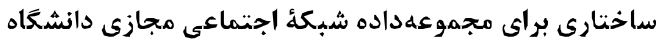 تحصيلات تكميلى علوم يُايه زنجان}

(Table-5): The evaluation of best similarity metrics between

\begin{tabular}{|c|c|}
\hline معيار شباهت ساختارى & ميانكين AUCهاى به دست \\
\hline شباهت شبكه & 0.56 \\
\hline جاكارد & 0.56 \\
\hline شباهت كوسينوسى & 0.53 \\
\hline L نرمال L1 & 0.51 \\
\hline
\end{tabular}

(جدول - ()): ارزيابى معيار اصلح از بين معيار هاى نامزد شباهت

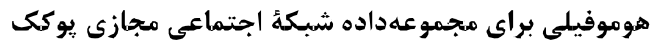

(Table-6): The evaluation of best similarity metrics between network similarity metrics on IASBS Social

\begin{tabular}{|c|c|c|}
\hline معيار شباهت & 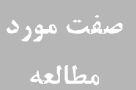 & 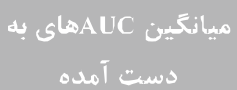 \\
\hline OF & جنسيت & 0.49 \\
\hline $\mathrm{IOF}$ & جنسيت & 0.46 \\
\hline
\end{tabular}

همان طور كه در جداول (Q و V شان ماده شده است،

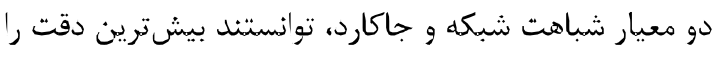

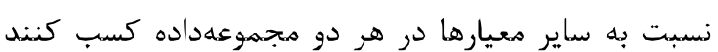


تجميع ويزّكىهاى هوموفيلى و ساختارى كمك كند، كه إنه

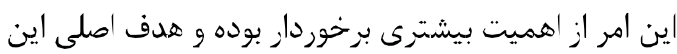

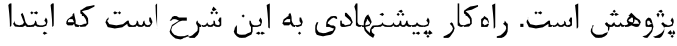

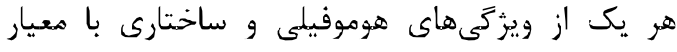

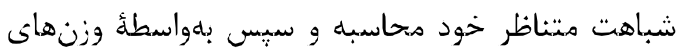

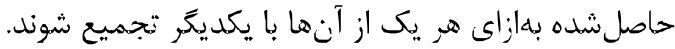

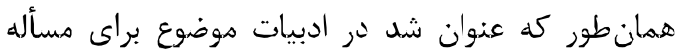

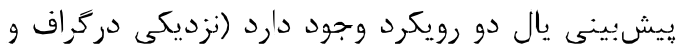

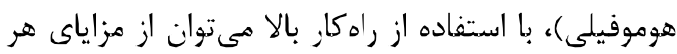

دو رويكرد متناظر با درجه اهميت هر يك بهر همند شد.

(جدول-••): نتايج تجميع معيار هاى هوموفيلى و ساختارى براى مجموعهداده شبكئ اجتماعى مجازي دانشيكاه تحصيلات تكميلى علوم يايه.

(Table-10): Evaluation results for aggregation homophily features and network features on LASBS Social.

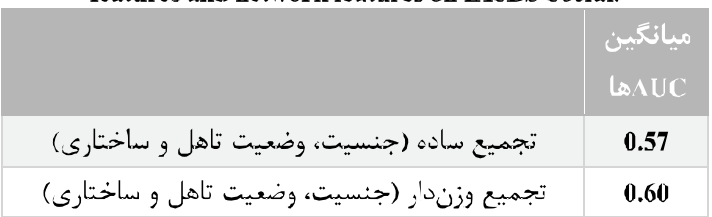

در جدول (• (1) نتايج تجميع معيار ها به صورت وزندار

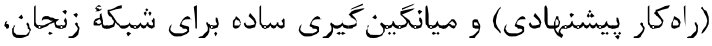

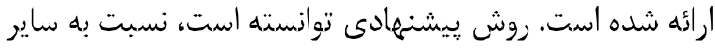

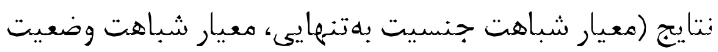

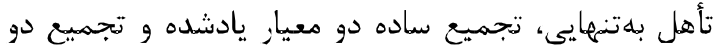
معيار يادشده بهصورت وزندار) دقت را ب. •• افزايش دهد.

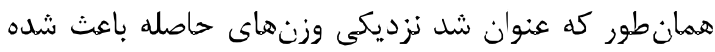
است كه هيزان افزايش دقت قابل هلاحظه نشون؛ درواقع ميزان

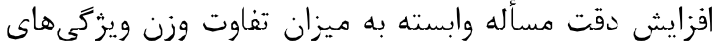

حاصلشده (ميزان تفاوت اهميت ويزگى هاى شبكه) است.

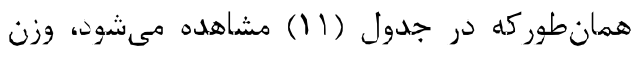

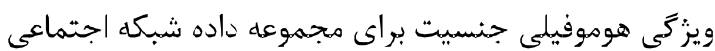
مجازى يوكى منفى شده است و همانطور كه توضيح داده

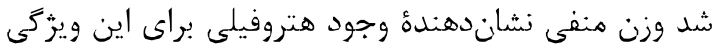

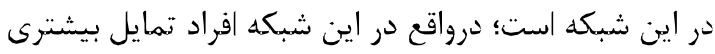
به برقرارى ارتباط با جنس مخالف از خود نشان دادهاند. از از

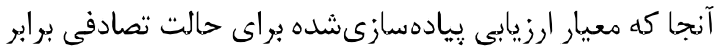
است با مقدار هنجاه درصد، لذا انتظار مى رود كه (با توجه به به به بهايه

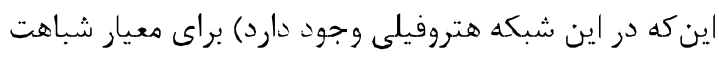
هوموفيلى جنسيت اين مقدار زير ينجاه درصد حاصل شود.
همانطور كه در جدول (9) مشاهده مىشود، نتايج حاصل بر روى شبكه اجتماعى مجازى دانشعاه تحصيلات

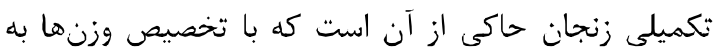

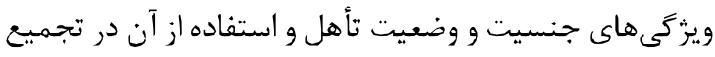
آنها براى بهدست آوردن معيار شباهت، توانستهايم بر دقت

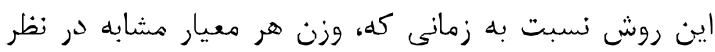

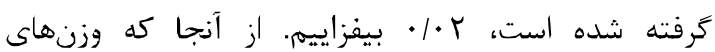
حاصلشده اختلاف ناجيزى با يكديخر دارند، درنظرَّفتن

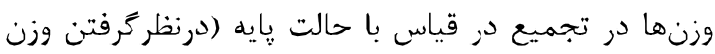

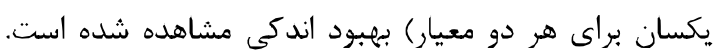
بهطورطبيعى هر جه اختلاف وزنها براى معيارهاى شباهت هوهوفيلى بيشتر باشند، اختلاف دقت نتيجه روش ارائهشده با باليا

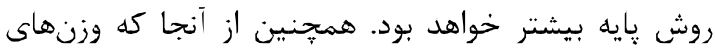
تخصيص داده شده بهترتيب به شباهت ساختارى، شباهت

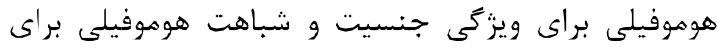
ويزگى وضعيت تأهل، بيشترين اعداد را نسبت داده است،

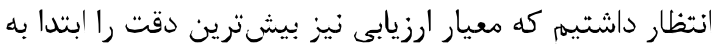

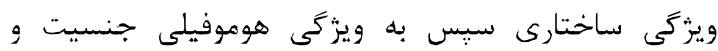
درنهايت به ويزگكى هوموفيلى وضعيت تأهل نسبت دهد، كه

$$
\text { نتايج منطبق بر همين امر است. }
$$

(جدول -1): نتايج ارزيابى بهازاى هر ويزَّى شباهت براى

$$
\begin{aligned}
& \text { مجموعهداده شبكئ اجتماعى مجازى دانشئاه } \\
& \text { تحصيلات تكميلى علوم بايه }
\end{aligned}
$$

\begin{tabular}{|c|c|c|}
\hline \multicolumn{3}{|c|}{ IASBS Social } \\
\hline & ميانكين & ميLين \\
\hline شباهت ساختارى (NS) & 0.48 & 0.56 \\
\hline شباهت هوهوفيلى (جنسبت) & 0.29 & 0.55 \\
\hline شباهت هوموفيلمى (وضعيت تاهل) & 0.24 & 0.52 \\
\hline
\end{tabular}

(Table-8): Evaluation results for each similarity feature on

(جدول-9) : نتايج ارزيابى تجميع ويرٔى هاى هوموفيلى براى

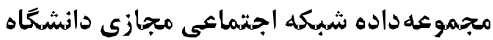
تحصيلات تكميلى علوم بايها

\begin{tabular}{|c|c|}
\hline & 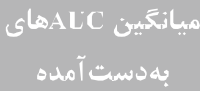 \\
\hline تجميع ساده دو هعيار هوموفيلى & 0.55 \\
\hline تجميع وزندار دو معيار هوموفيلى & 0.57 \\
\hline
\end{tabular}

(Table-9): Evaluation results for aggregation homophily features on IASBS Social.

T- محاسبة وزنهاى ويزگى هاى هوموفيلى و ساختارى علاوهبر حل جالث بالا (كه توضيح داده شد)، مىتواند دائ در 
روشهاى تكميل اطلاعات در حوزه علوم شبكه اين نقص

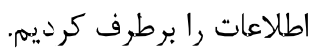

براساس مطالعات صورت كرفته، هعيارهاى شباهتى از

هر دو دسته هعيارهاى شباهت هوموفيلى و ساختارى بهعنوان

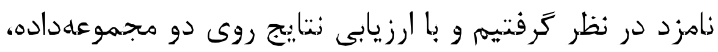
بهترين معيارها را بركزيديهم.

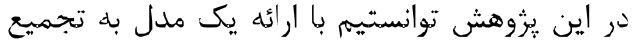
وزندار هعيارهاى شباهت هوموفيلى وساختارى بيردازيهم.

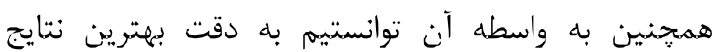
معيارهاى مبتنى بر همسايگى كره بيافزاييمه از مزاياى اين كار

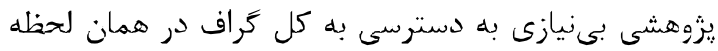
است و فقط تصوير لحظهاى شبكه در زمان كنشته هي تونواند

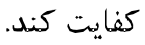

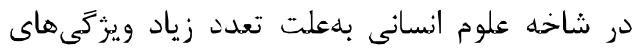

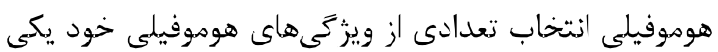

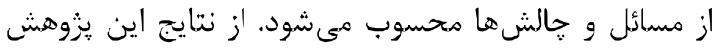

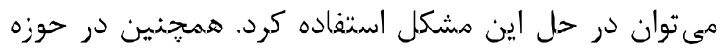

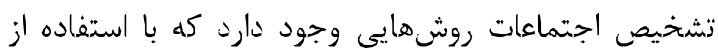
هوموفيلى و نزديكى در كراف به تشخيص اجتماعات

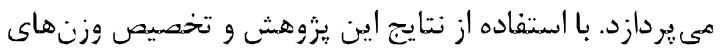

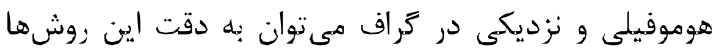

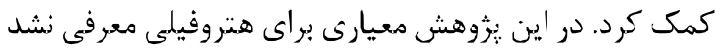

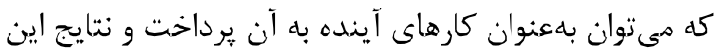

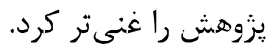

\section{6- References مراجع}

[1] d. boyd and N. B. Ellison, "Social network sites: Definition, history, and scholarship," Journal of Computer-Mediated Communication, vol. 13, no. 1, pp. 210-230, 2007.

[2] H. Gangadharbatla, "Facebook me: Collective self-esteem, need to belong, and internet self-efficacy as predictors of the iGeneration's attitudes toward social networking sites," Journal of interactive advertising, vol. 8, no. 2, pp. 5-15, 2008.

[3] M. E. J. Newman, "The structure and function of complex networks," SIAM Review, vol. 45, no. 2, p. 167-256, 2003.

[4] V. Ranjbar, M. Salehi, P. Jandaghi, and M. Jalili. "QANet: Tensor Decomposition Approach for Query-based Anomaly Detection in IIetcrogencous Information Networks." IEEE Transactions on Knowledge and Data Engineering, 31(11), pp.2178-2189, 2019.
(جدول -11): نتايج وزنهاى حاصل شده بهازاى هر ويثزى

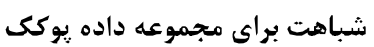

(Table-11): Results of the weights obtained per similarity feature on Pokec Social

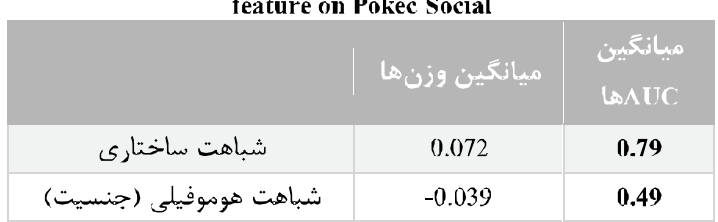

همانطور كه در جدول (11) مشاهده مىشود، مقدار

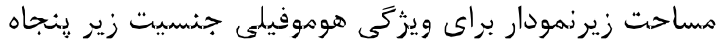

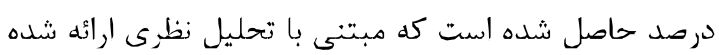

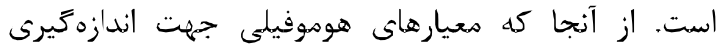
هوموفيلى ارائه شدهاند و كارايى براى هتروفيلى نداشته، آنائ اضافهكردن ويزگى هوموفيلى به ساختارى بهطورطبيعى بايد دقت را كاهش دهد. همانطور كل در جدول (11) مشاهده مىشود، ميزان مساحت زيرنهودار هحاسبهشده براى ويزئى

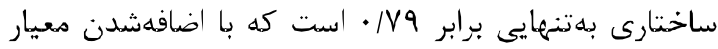

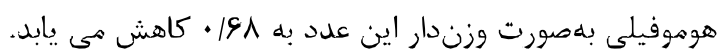

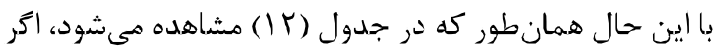
اضافهردن معيار هوموفيلى جنسيت بلهصورت ميانكيرى

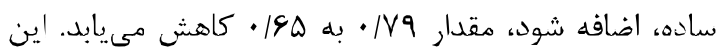
امر بدان معناست كه با احتساب اين كه در شبكه هتروفيلى ماري وجود دارد، ولى ميزان اهميت آن از ويزگى ساختارى كمتر

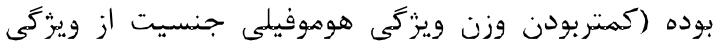

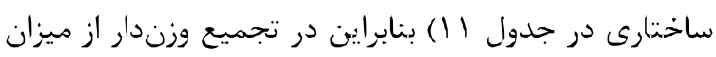
اهميت آن نسبت به هيانگين گيرى ساده كاسته شده و توانسته

$$
\text { است، نزول كمترى يبيدا كند. }
$$

(جدول-1) : نتايج تجميع معيارهاى هوموفيلى و ساختارى براى مجموعه داده بوكى مئك

(Table-12): Evaluation results for aggregation homophily features and network features on Pokec Social.

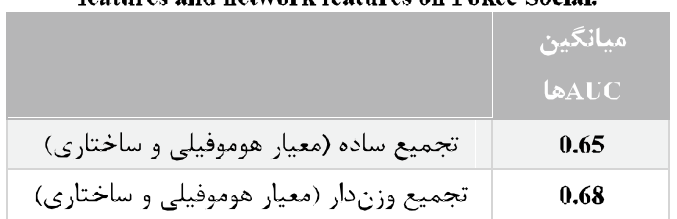

\section{ه- نتيجه}

در اين يُؤهش در ابتدا مجموعهداده شبكة اجتماعى مجازى

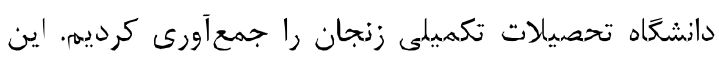
هجم.وعهداده داراى نقص اطلاعات كاربران بود. براى حل حل آن آن آن

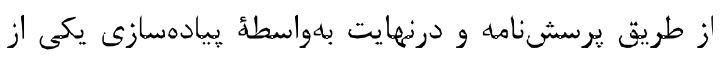


Statistical Mechanics and its Applications, vol. 390, no. 6 , pp. 1150-1170, 2011.

[15] C. S. a. D. Waltz, "Toward memory based reasoning," $\Lambda$ CM, vol. 29, no. 12, pp. 1213-1228, 1986.

[16] E. Eskin, A. Arnold, M. Prerau, L. Portnoy and S. Stolfo, "A geometric framework for unsupervised anomaly detection: Detecting intrusions in unlabeled data," Applications of data mining in computer security, vol. 6, pp. 77-102, 2002

[17] D. W. Goodall, "A New Similarity Index Based on Probability," Biometrics, vol. 22, no. 4, pp. 882-907, 1966.

[18| T. J. Cover TM, Elements of information theory, New York: Wiley-Interscience, 1991.

[19] P. Jaccard, Etude de la distribution florale dans une portion des Alpes et du Jura, Naturelles: Bulletin de la Societe Vaudoise des Sciences Naturelles, 1901.

[20] E. A. L. A. Adamic, "Friends and neighbors on the Web," Social Networks, vol. 25, no. 3, pp. 211-230, 2003.

[21] M. Jalili, Y. Orouskhani, M. Asgari, N. Alipourfard and M. Perc, "Link prediction in multiplex online social networks," Royal Society Open Science, vol. 4, no. 2, 2017.

[22] Z. Wu, Y. Lin and J. Wang, "Link prediction with node clustering coefficient," Physica $\Lambda$ : Statistical Mechanics and its Applications, vol. 452, pp. 1-8, 2016.

[23] Sh .Najari, M. Salehi, V. Ranjbar, and M. Jalili. "Link prediction in multiplex networks based on interlayer similarity." Physica A: Statistical Mechanics and its Applications, 2019 ..

124| M. Deshpande and G. Karypis, "Item-based top-n recommendation algorithms," ACM Transactions on Information Systems (TOIS), vol. 22, no. 1, pp. 143-177, 2004.

|25] T. Zhou, L. Lü and Y.-C. Zhang, "Predicting missing links via local information," The European Physical Journal B-Condensed Matter and Complex Systems, vol. 71, no. 4, pp. $623-630,2009$.

[26] H. Shakibian and N. Moghadam Charkari, "Mutual information model for link prediction in heterogeneous complex networks," Scientific Reports, vol. 7, 2017.

[27] H. Zhao, Q. Yao, J. Li, Y. Song and D. Lee, "Meta-Graph Based Recommendation Fusion over Heterogeneous Information Networks," in Proceedings of the 23rd ACM SIGKDD International Conference on Knowledge Discovery and Data Mining, 2017.

[28] X. Yang, T. Deng, Z. Guo and . Z. Ding, "Advertising Keyword Recommendation based on Supervised Link Prediction in MultiRelational Network," in Proceedings of the
[5] R. Albert and A.-L. Barabasi, "Statistical mechanics of complex networks," Reviervs of Modern Physics, vol. 74, no. 47, January 2002.

[6] C. Zhong, M. Salchi, S. Shah, M. Cobzarenco, N. Sastry and M. Cha, "Social bootstrapping: how pinterest and last. fin social communitics benefit by borrowing links from facebook," in Proceedings of the $23 \mathrm{rd}$ international conference on World wide web, 2014.

[7] S. N. Dorogovtsev and J. F. F. Mendes, Evolution of networks: From biological nets to the Internet and WWW, Oxford University Press, 2003.

[8] J. Leskovec and L. Backstrom, "Supervised random walks: predicting and recommending links in social networks," in Proceedings of the fourth ACM international conference on Web search and data mining, 2011.

[9] M. McPherson, L. Smith-Lovin and J. M Cook, "Birds of a Feather Homophily in Social Networks," jstor, vol. 27, pp. 415-444, 2001.

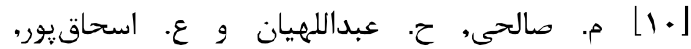

$$
\begin{aligned}
& \text { "هوموفيلى در شبكهماى اجتماعى مجازى (مطالعه مانه } \\
& \text { موردى شبكه اجتماعى مجازى دانثگاه تحصيلات } \\
& \text { تكميلى زنجان)," فصلنامه مطالعات رسانهای لهاى }
\end{aligned}
$$

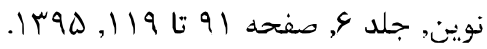

[10] A. Eshaghpour, M. Salehi and H. Abdollahyan, "Homophily in Virtual Social Networks: A Case Study of Virtual Social Network in Graduate University of Zanjan," New media studies, vol. 2, no. 6, pp. 93-120, 2016.

[11] S. Boriah, V. Chandola and V. Kumar, "Similarity measures for categorical data: A comparative evaluation," Red, vol. 30, no. 2, pp. 3, 2008.

[12| C. G. Akcora, B. Carminati and E. Ferrari, "User similarities on social networks," Social Network Analysis and Mining, vol. 3, no. 3, pp. 475-495, 2013.

$$
\begin{aligned}
& \text { [r] ] م. حسينى، م. نصرالهى، ع. بقايى، "يك سامانه }
\end{aligned}
$$

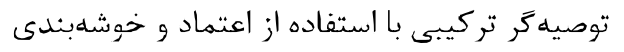

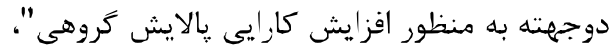

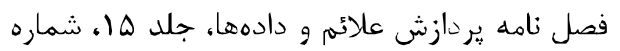

$$
\begin{aligned}
& \text { r، صفحه }
\end{aligned}
$$

|13| Hosseini M, Nasrollahi M, Baghaei A. "A hybrid recommender system using trust and bi-clustering in order to increase the efficiency of collaborative filtering". JSDP.; vol.15 (2) . pp.119-132, 2018.

[14] L. Lü and T. Zhou, "Link prediction in complex networks: A survey," Physica A: 


$$
\begin{aligned}
& \text { دريافت درجه دكترا در همين رشته از دانشعاه شريف شد. }
\end{aligned}
$$

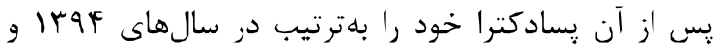

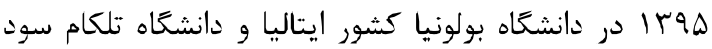

$$
\begin{aligned}
& \text { ياريس (فرصت مطالعاتى) كذر اند. وى هم اكنون بهعنوان عضو } \\
& \text { هيئت علمى كروه بين رشتهاى فناورى دانشعاه تهران، با مرتبه } \\
& \text { دانشيارى مشغول به فعاليت است. زمينههاى يزوهشى ايشان } \\
& \text { شامل شبكههاى اجتماعى مجازى، اينترنت اشيا و شبكههاى }
\end{aligned}
$$

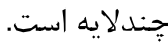

$$
\begin{aligned}
& \text { نشانى رايانامه ايشان عبارت است ازي }
\end{aligned}
$$

mostafa_salchi@ut.ac.ir

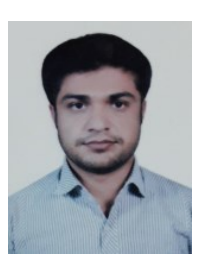

$$
\begin{aligned}
& \text { وحيد رنجبر كارشناسى و كارشناسى } \\
& \text { ارشد خود را در رشته مهندسى فناورى }
\end{aligned}
$$

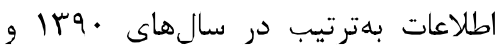

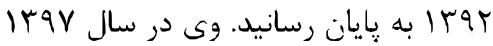

$$
\begin{aligned}
& \text { دكتراى تخصصى خود را در رشته فناورى }
\end{aligned}
$$

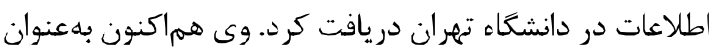
عضو هيئت علمى دانشكده ههندسى كامييوتر دانشعاه يزن مشغول به فعاليت است. زمينهاى ئزوهشى مورد علاقه ايشان تحليل شبكههاى اطلاعاتى، ياد ميرى ماشين و كلان داده بهن

$$
\text { نشانى رايانامه ايشان عبارت است از: }
$$

vranjbar@yazd.ac.ir 26th International Conference on World Wide Web Companion, Perth, Australia, 2017.

[29] M. E. J.33 Newman, Networks An Introduction, New York: Oxford University Press Inc, 2010 .

[30] R. Milo , S. Shen-Orr, S. Itzkovitz, N. Kashtan, D. Chklovskii and U. Alon, "Network motifs: simple building blocks of complex networks," Science, vol. 298, no. 5594, pp. 824-827, 2002.

[31] L. Takac and M. Zabovsky, "Data Analysis in Public Social Networks," in International Scientific Conference and International Workshop Present Day Trends of Innovations, 2012

「32] K.-L. Goh, B. Kahng and D. Kim, "Universal Behavior of Load Distribution in Scale-Free Networks," Physical Review Letters, vol. 87, no. $27,2001$.

[33] M. McPherso, L. Smith-Lovin and J. M Cook, "Classification of scale free networks," Proceedings of the National Academy of Sciences of the United States of America, vol. 99, 2002.

[34] J. A Smith, M. McPherson and L. SmithLovin, "Social Distance in the United States Sex, Race, Religion, Age, and Education Homophily among Confidants, 1985 to 2004," American Sociological Review, vol. 79, no. 3, pp. 432-456, 162014.

[35] X. Han, "Mining user similarity in online social networks: analysis, modeling and applications," 2015.

[36] J. Hyung Kang and K. Lerman, "Using Lists to Measure Homophily on Twitter," in Workshops at the Twenty-Sixth AAAI Conference on Artificial Intelligence, 2012.

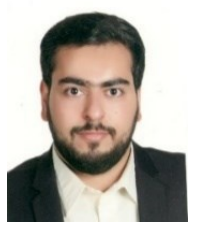

$$
\begin{aligned}
& \text { عليرضا اسحاقيور متولد و\&با، } \\
& \text { كارشناسى و كارشناسى ارشد خود راستون }
\end{aligned}
$$
رسانيد، وى هماكنون بهعنوان كارشناس ارشد SOC با بان

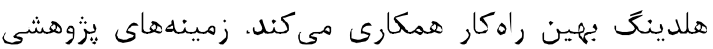

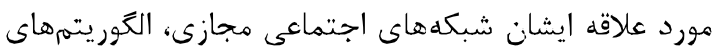

$$
\text { زنتيك جندهدفه و امنيت اطلاعات است. }
$$$$
\text { نشانى رايانامه ايشان عبارت است ازئ }
$$

\section{a_eshaghpoor@ut.ac.ir}

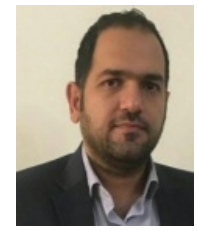

$$
\begin{aligned}
& \text { مصطفى صالحى كارشناسى و كارشناسى } \\
& \text { ارشد خود را در رشتئ مهرندسى كامييوتر }
\end{aligned}
$$

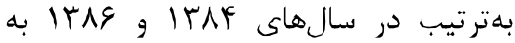

$$
\begin{aligned}
& \text { يايان رسانيد. او در سال |وبال موفق به }
\end{aligned}
$$

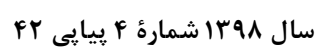

